University of Nebraska - Lincoln

DigitalCommons@University of Nebraska - Lincoln

Whole-Stream Response to Nitrate Loading in Three Streams

Draining Agricultural Landscapes

John H. Duff

USGS, jhduff@usgs.gov

Anthony J. Tesoriero

USGS

William B. Richardson

USGS

Eric A. Strauss

University of Wisconsin-La Crosse

Mark Munn

USGS

Follow this and additional works at: https://digitalcommons.unl.edu/usgsstaffpub

Part of the Earth Sciences Commons

Duff, John H.; Tesoriero, Anthony J.; Richardson, William B.; Strauss, Eric A.; and Munn, Mark, "WholeStream Response to Nitrate Loading in Three Streams Draining Agricultural Landscapes" (2008). USGS Staff -- Published Research. 25.

https://digitalcommons.unl.edu/usgsstaffpub/25

This Article is brought to you for free and open access by the US Geological Survey at DigitalCommons@University of Nebraska - Lincoln. It has been accepted for inclusion in USGS Staff -- Published Research by an authorized administrator of DigitalCommons@University of Nebraska - Lincoln. 


\title{
Whole-Stream Response to Nitrate Loading in Three Streams Draining Agricultural Landscapes
}

\author{
John H. Duff, * Anthony J. Tesoriero, and William B. Richardson USGS \\ Eric A. Strauss University of Wisconsin-La Crosse \\ Mark D. Munn USGS
}

Physical, chemical, hydrologic, and biologic factors affecting nitrate $\left(\mathrm{NO}_{3}{ }^{-}\right)$removal were evaluated in three agricultural streams draining orchard/dairy and row crop settings. Using 3-d "snapshots" during biotically active periods, we estimated reachlevel $\mathrm{NO}_{3}{ }^{-}$sources, $\mathrm{NO}_{3}{ }^{-}$mass balance, in-stream processing (nitrification, denitrification, and $\mathrm{NO}_{3}^{-}$uptake), and $\mathrm{NO}_{3}^{-}$ retention potential associated with surface water transport and ground water discharge. Ground water contributed 5 to $11 \%$ to stream discharge along the study reaches and 8 to $42 \%$ of gross $\mathrm{NO}_{3}^{-}$input. Streambed processes potentially reduced 45 to $75 \%$ of ground water $\mathrm{NO}_{3}{ }^{-}$before discharge to surface water. In all streams, transient storage was of little importance for surface water $\mathrm{NO}_{3}^{-}$retention. Estimated nitrification (1.6-4.4 $\mathrm{mg} \mathrm{N} \mathrm{m}^{-2} \mathrm{~h}^{-1}$ ) and unamended denitrification rates $\left(2.0-16.3 \mathrm{mg} \mathrm{N} \mathrm{m}^{-2} \mathrm{~h}^{-1}\right)$ in sediment slurries were high relative to pristine streams. Denitrification of $\mathrm{NO}_{3}{ }^{-}$was largely independent of nitrification because both stream and ground water were sources of $\mathrm{NO}_{3}{ }^{-}$. Unamended denitrification rates extrapolated to the reach-scale accounted for $<5 \%$ of $\mathrm{NO}_{3}{ }_{3}^{-}$ exported from the reaches minimally reducing downstream loads. Nitrate retention as a percentage of gross $\mathrm{NO}_{3}{ }^{-}$inputs was $>30 \%$ in an organic-poor, autotrophic stream with the lowest denitrification potentials and highest benthic chlorophyll $\boldsymbol{a}$, photosynthesis/respiration ratio, $\mathrm{pH}$, dissolved oxygen, and diurnal $\mathrm{NO}_{3}^{-}$variation. Biotic processing potentially removed $75 \%$ of ground water $\mathrm{NO}_{3}{ }^{-}$at this site, suggesting an important role for photosynthetic assimilation of ground water $\mathrm{NO}_{3}{ }^{-}$relative to subsurface denitrification as water passed directly through benthic diatom beds.

Copyright $\odot 2008$ by the American Society of Agronomy, Crop Science Society of America, and Soil Science Society of America. All rights reserved. No part of this periodical may be reproduced or transmitted in any form or by any means, electronic or mechanical, including photocopying, recording, or any information storage and retrieval system, without permission in writing from the publisher.

Published in J. Environ. Qual. 37:1133-1144 (2008). doi:10.2134/jeq2007.0187

Received 17 Apr. 2007.

*Corresponding author (jhduff@usgs.gov).
$\mathrm{H}$ UMANs have extensively modified the global $\mathrm{N}$ cycle through production of $\mathrm{N}$ fertilizers, cultivation of $\mathrm{N}$-fixing crops, animal waste disposal practices, and the combustion of fossil fuels (Galloway et al., 1995; Vitousek et al., 1997). These human alterations have approximately doubled the rate of $\mathrm{N}$ inputs into the terrestrial $\mathrm{N}$ cycle and have greatly increased $\mathrm{N}$ transfer by rivers to estuaries and oceans (Vitousek et al., 1997). Increased N loading has polluted ground water (Spalding and Exner, 1993; Nolan, 1999; Nolan and Stoner, 2000; Tesoriero et al., 2007), increased the green house gas $\mathrm{N}_{2} \mathrm{O}$ (Matson et al., 1997, 1999), acidified soils and sensitive freshwaters (Vitousek et al., 1997), and generated an array of coastline problems (Howarth et al., 2000; Cloern, 2001). In the next $50 \mathrm{yr}$, agriculture is expected to expand to meet food demands from a $50 \%$ increase in global population and lead to a 2.5 -fold increase in $\mathrm{N}$-driven eutrophication (Tilman et al., 2001). Because streams and rivers transport much of the $\mathrm{N}$ load, quantitative understanding of how agricultural loading affects $\mathrm{N}$ transport and cycling in rivers, lakes, and estuaries is sorely needed (Peterson et al., 2001).

Agricultural landscapes cover a large percentage of the continental land mass in the USA and contribute to an extensive drainage network. Twenty-one percent of stream miles in the West, $27 \%$ in the Plains and Lowlands, and 42\% in the Eastern Highlands transport agricultural runoff (USEPA, 2006). Collectively, these drainages convey a large percentage of $\mathrm{N}$-enriched water to main-stem rivers where $\mathrm{N}$-retention processes are disproportionately small compared with transport (Alexander et al., 2000; Richardson et al., 2004).

Most current understanding of $\mathrm{N}$ uptake and transformation in fluvial environments is from relatively small, pristine, low-N streams (e.g., Hall and Tank, 2003; Mulholland et al., 2004). Small, pristine streams and rivers are more effective at $\mathrm{N}$ processing and retention than large watersheds (Alexander et al., 2000; Peterson et al., 2001), but pristine streams differ substantially from those in agricultural regions where $\mathrm{N}$ concentrations are higher, riparian vegetation is reduced, and riparian flowpaths are often bypassed with tile drainage (e.g., Royer et al., 2004; Bernot et al., 2006).

Using a variety of approaches to estimate denitrification, Royer et al. (2004), Böhlke et al. (2004), Smith et al. (2006), and Bernot

J.H. Duff, U.S. Geological Survey, Water Resources Div., 345 Middlefield Road, MS 439, Menlo Park, CA 94025. A.J. Tesoriero, U.S. Geological Survey, Portland, OR. W.B. Richardson, U.S. Geological Survey, La Crosse, WI. E.A. Strauss, Univ. of Wisconsin, La Crosse, WI. M.D. Munn, U.S. Geological Survey, Tacoma, WA.

Abbreviations: AFDM, ash-free dry mass; DO, dissolved oxygen; DON, dissolved organic nitrogen; TN, total nitrogen; TP, total phosphorus; PAR, photosynthetically active radiation; $\mathrm{P} / \mathrm{R}$ ratio, photosynthesis-respiration ratio. 
et al. (2006) suggest that microbial activity in low- to mediumorder agricultural streams has a limited impact on long-term $\mathrm{N}$ loads despite relatively high denitrification potential. There is little evidence for universal $\mathrm{C}$ or $\mathrm{O}_{2}$ limitation of denitrification; rather, hydrologic and geomorphic channel characteristics exert considerable control on $\mathrm{N}$ transport and retention (Hill and Lymburner, 1998; Royer et al., 2004). Understanding hydrologic and physical constraints for biological $\mathrm{N}$ processing in agricultural drainages is important because in-stream $\mathrm{N}$ processing near the source has the best chance to reduce loads before export to larger streams where retention is likely smaller.

The objective of this study was to determine the whole-stream response to $\mathrm{NO}_{3}{ }^{-}$loading in three geographically dispersed streams draining agricultural settings with contrasting channel characteristics, riparian vegetation, and sediment organic content. All sites drained intensive agricultural watersheds, with streamwater $\mathrm{NO}_{3}{ }^{-}$levels between 1 and $3 \mathrm{mg} \mathrm{N} \mathrm{L}^{-1}$. We connected surface water, streambed, and ground water hydrologic and microbial processes to $\mathrm{N}$ transport and retention using reach-scale modeling, N-mass balances, laboratory estimates of nitrification and denitrification potentials, and in situ benthic flux chambers.

\section{Site Descriptions}

The studies were conducted in September 2003, May 2004, and September 2004 in the Yakima River Basin, WA (DR2 Drain); the Delmarva Peninsula, MD (Morgan Creek); and Central Nebraska Plains, NE (Maple Creek). The climate, irrigation practices, and crop types contrast among the sites (Capel et al., 2008). All three streams were sampled at low flow, and no stream had tile drainage near the study site. All three reaches were companion studies with $\mathrm{N}$ fate and transport studies in adjacent shallow aquifers (Green et al., 2008) and ground water discharge (Puckett et al., 2008). Additional descriptions of all sites can be found in Capel et al. (2008).

\section{DR2 Drain, Washington}

DR2 is an incised drainage channel in south-central Washington located in an area of extensive orchards, vineyards, row crops, and dairies. The climate is arid/semiarid, and the irrigation demand during the growing season is supplied by the Yakima River. DR2 had a mean depth and width of approximately $0.4 \mathrm{~m}$ and $2.0 \mathrm{~m}$, and the reach was $428 \mathrm{~m}$ long (Table 1). Grass separated the channel from irrigated pasture on the right bank and dairy feedlot on the left bank, resulting in high light penetration. The streambed consisted of sand and silt with relatively high organic matter content.

Table 1. Physical stream characteristics.

DR2 Drain, WA Maple Creek, NE Morgan Creek, MD

\begin{tabular}{llll}
\hline Discharge $\left(\mathrm{m}^{3} \mathrm{~s}^{-1}\right)$ & 0.144 & 0.443 & 0.235 \\
Reach length $(\mathrm{m})$ & 428 & 1145 & 1145 \\
Width $(\mathrm{m})$ & 2.0 & 10.8 & 4.2 \\
Depth $(\mathrm{m})$ & 0.42 & 0.15 & 0.41 \\
Dominant sediment & sand/silt & sand & silt/clay \\
\hline
\end{tabular}

\section{Maple Creek, Nebraska}

Maple Creek is a natural stream drainage in eastern $\mathrm{Ne}$ braska located in an area of extensive row crop agriculture (corn [Zea maze], soybeans [Glycine max L.], and alfalfa [Medicago sativa L.]). The climate is humid continental with supplemental irrigation from ground water. The Maple Creek reach is approximately $0.2 \mathrm{~m}$ deep and $11.0 \mathrm{~m}$ wide with a large corn field on the left bank and pasture and soybean on the right bank (Table 1). Riparian forest unevenly lines both banks, but the wide channel permits high light penetration. The streambed consists of sand and gravel alluvial deposits with low sediment organic matter. The study reach was 1145 $\mathrm{m}$ long.

\section{Morgan Creek, Maryland}

Morgan Creek is located in eastern Maryland. The climate is humid subtropical, with the water demand supplied by rainfall. Corn and soybeans are grown on the left bank, and pasture for organic dairy lines the right bank. A thick wooded riparian zone results in low light penetration in Morgan Creek. The study reach was approximately $0.4 \mathrm{~m}$ deep, $4.0 \mathrm{~m}$ wide, and $1145 \mathrm{~m}$ long (Table 1). Numerous surface water tributaries along both banks originate as ground water seeps in the adjacent floodplain. An impervious clay layer within the study reach prevents ground water discharge through the streambed (Puckett et al., 2008). The streambed consists largely of silt and clay with high sediment organic matter. Large woody debris is completely absent from DR2, uncommon in Maple Creek, and common in Morgan Creek.

\section{Materials and Methods}

\section{Hydrologic Characterization}

At each study reach, discharge was measured by tracer injection for $72 \mathrm{~h}$. The injectate consisted of sodium bromide $(\mathrm{NaBr})$ mixed with approximately $600 \mathrm{~L}$ of stream water (final concentration, $160-310 \mathrm{~g} \mathrm{Br}^{-} \mathrm{L}^{-1}$ ) in a plastic stock tank. The injectate was pumped into the stream at $0.1 \mathrm{~L} \mathrm{~min}^{-1}$ using a rotary-drive, positive-displacement piston pump controlled by a data logger. Bromide was sampled at the base of a mixing reach and at two or three downstream locations 100 to $400 \mathrm{~m}$ apart. Ground water discharge was calculated by tracer dilution between upstream and downstream stations. Discharges from tributaries (at Morgan Creek) were measured independently using Rhodamine WT dye tracer.

Approximately 60 to $80 \mathrm{Br}^{-}$samples were collected intensively during the rise of the tracer at each location and then every $4 \mathrm{~h}$ during the plateau to estimate travel time between stations, stream discharge, ground water inflow, and transient storage. Water samples were collected upstream of the injection to correct for background $\mathrm{Br}^{-}$concentration. Three synoptic sampling "sweeps" were done at the $\mathrm{Br}^{-}$plateau to follow a packet of water from the injection site to the base of the reach. By sampling the same "packet" of water as it progressed downstream, convective effects on $\mathrm{Br}^{-}$transport could be eliminated as a factor in downstream tracer decrease. 
A one-dimensional transport with inflow and storage model (OTIS-P) was fitted to the concentration versus time data collected during the rise to describe the transport processes. The advectivedispersion model with a transient storage term accurately described tracer concentrations in a variety of stream environments (Bencala and Walters, 1983; Jackman et al., 1984; Runkel, 1998). Transient storage parameters modeled include the dispersion coefficient $(D)$, storage zone exchange coefficient $(\alpha)$, and cross-sectional area of the storage zone $(A)$ and stream channel $(A)$. We used model results to calculate the ratio of the cross-sectional area of the storage zone to the stream channel $(A / A)$, median transient-storage time $\left(F_{\text {med }}{ }^{200}\right)$ (Runkel 2002), average hydrologic residence time in the storage zone $\left(t_{\text {sto }}\right)$ (Harvey et al., 1996), and depth of the storage zone $\left(d_{s t o}\right)$ for streams with a width/depth ratio greater and less than 20 (Harvey and Wagner, 2000).

\section{Reach-Scale $\mathrm{NO}_{3}$ - Mass Balance}

A reach-scale $\mathrm{NO}_{3}{ }^{-}$mass balance was determined at each stream during the 72-h tracer injection under background nutrient conditions. Nitrate mass balances were calculated from upstream inputs, ground water inputs, downstream output, and $\mathrm{NO}_{3}{ }^{-}$processing estimates (Eq. [1]):

$$
\left(\mathrm{Q}_{1} \times \mathrm{C}_{1}\right)+\left(\mathrm{Q}_{g w} \times \mathrm{C}_{g w}\right)=\left(\mathrm{Q}_{2} \times \mathrm{C}_{2}\right)+\mathrm{NO}_{3}^{-} \text {processing }
$$

where $\left(\mathrm{Q}_{1} \times \mathrm{C}_{1}\right)$ is upstream $\mathrm{NO}_{3}{ }^{-}$load, $\left(\mathrm{Q}_{g w} \times \mathrm{C}_{g w}\right)$ is ground water $\mathrm{NO}_{3}{ }^{-}$load, $\left(\mathrm{Q}_{2} \times \mathrm{C}_{2}\right)$ is downstream $\mathrm{NO}_{3}^{-}$ load, and $\mathrm{NO}_{3}{ }^{-}$processing is the biotic $\mathrm{NO}_{3}{ }^{-}$processing in the sediment due to nitrification, assimilation, and denitrification. The gross $\mathrm{NO}_{3}{ }^{-}$influx from ground water $\left(\mathrm{Q}_{g w} \times \mathrm{C}_{g w}\right)$ was calculated as ground water discharge times the median ground water $\mathrm{NO}_{3}{ }^{-}$concentration. The median ground water $\mathrm{NO}_{3}{ }^{-}$ concentrations were estimated from small-diameter drive points deployed throughout the reach extending 0.1 to 1.0 $\mathrm{m}$ below the bed (10-30 samples) and from near-stream well data (Puckett et al., 2008). Biotic $\mathrm{NO}_{3}{ }^{-}$processing in the reach was estimated by solving Eq. [1] for the term $\mathrm{NO}_{3}^{-}$ processing and is defined as positive for $\mathrm{NO}_{3}{ }^{-}$loss and negative for $\mathrm{NO}_{3}{ }^{-}$gain. Within-reach net $\mathrm{NO}_{3}{ }^{-}$flux from the bed to the surface water (or surface water to the bed) was estimated from the upstream-downstream change in $\mathrm{NO}_{3}{ }^{-}$mass assuming water column cycling was insignificant relative to benthic cycling and is defined by Equation [2]:

$$
\text { Net } \begin{aligned}
\mathrm{NO}_{3}{ }^{-} \text {flux } & =\left(\mathrm{Q}_{g w} \times \mathrm{C}_{g w}\right)-\mathrm{NO}_{3}^{-} \text {processing } \\
& =\left(\mathrm{Q}_{2} \times \mathrm{C}_{2}\right)^{-}-\left(\mathrm{Q}_{1} \times \mathrm{C}_{1}\right)^{\text {f }}
\end{aligned}
$$

In the case where gross $\mathrm{NO}_{3}{ }^{-}$influx in ground water was greater than the net $\mathrm{NO}_{3}{ }^{-}$efflux from the bed to surface water, $\mathrm{NO}_{3}{ }^{-}$retention was substituted for $\mathrm{NO}_{3}^{-}$processing in Eq. [1] and is defined by Eq. [3]:

$$
\mathrm{NO}_{3 \text { retention }}^{-}=\left(\mathrm{Q}_{g w} \times \mathrm{C}_{g w}\right)-\left[\left(\mathrm{Q}_{2} \times \mathrm{C}_{2}\right)-\left(\mathrm{Q}_{1} \times \mathrm{C}_{1}\right)\right]
$$

We expressed the amount of $\mathrm{NO}_{3}{ }^{-}$retained in the streambed as a fraction of the ground water input $\left(\mathrm{X}_{\text {NO3 retention }}\right)$ from Eq. [4]:

$$
\mathrm{X}_{N O 3 \text { retention }}=\mathrm{NO}_{3 \text { retention }}^{-} /\left(\mathrm{Q}_{\text {gw }} \times \mathrm{C}_{g w}\right)
$$

\section{Sediment Microbial Assays}

Sediment nitrification and denitrification rates were determined in laboratory slurry incubations made from sediment collected in cores $2.5 \mathrm{~cm}$ wide $\times 5.0 \mathrm{~cm}$ deep and stream water shipped overnight to the Upper Midwest Environmental Sciences Center in La Crosse, WI. Equally spaced cores ( $n=$ 10-13) were collected along a longitudinal transect encompassing one sub reach in DR2 and the entire study reach in Morgan and Maple Creeks. All incubations were initiated within $24 \mathrm{~h}$ of collection. Nitrification and denitrification rates were determined using the nitrapyrin and acetylene inhibition methods described by Strauss et al. (2004) and Richardson et al. (2004), respectively. Carbon and $\mathrm{N}$ limitations of denitrification were assessed by amending separate sediment samples with organic $\mathrm{C}$ (12 $\mathrm{mg} \mathrm{C} \mathrm{L}^{-1}$, as glucose) and $\mathrm{NO}_{3}^{-}\left(14 \mathrm{mg} \mathrm{N} \mathrm{L}^{-1}\right.$, as $\left.\mathrm{KNO}_{3}\right)$. Mean nitrification and denitrification rates and the mean denitrification response to amendments were analyzed using one-way ANOVA (Zar, 1974). Unamended denitrification rates were extrapolated to estimate reach-scale $\mathrm{N}$ loss.

Nitrate fluxes across the sediment-water interface were examined in open plastic cylindrical chambers that isolated a small area of the streambed and overlying water (approximately $25 \mathrm{~cm}$ diameter, five chambers each in DR2 and Maple Creek and 11 chambers in Morgan Creek, equally spaced along the study reach). Bromide was added as a conservative tracer. Stream water was collected and analyzed for $\mathrm{Br}^{-}$and $\mathrm{NO}_{3}{ }^{-}$before and after an 8-h incubation period.

\section{Surface Water Quality Parameters and Metabolism}

Water temperature, dissolved $\mathrm{O}_{2}(\mathrm{DO}), \mathrm{pH}$, specific conductance, and photosynthetically active radiation (PAR) were recorded continuously with YSI 600XLM data loggers (Yellow Springs Instruments Company, Yellow Springs, OH) and HOBO light meters (Onsett Corporation, Pocasset, $\mathrm{MA})$. Whole-reach community respiration, gross primary production, and photosynthesis/respiration (P/R) ratios were estimated using the open channel method (Marzolf et al., 1994 ) corrected to measure $\mathrm{O}_{2}$ flux via reaeration (Young and Huryn, 1998), similar to Hall and Tank (2003).

\section{Sediment Analyses}

Physical and chemical characteristics, including sediment size class, temperature, $\mathrm{pH}$, ash-free dry mass (AFDM), total $\mathrm{N}$ (TN), total organic $\mathrm{C}$ (TOC), exchangeable ammonium $\left(\mathrm{NH}_{4}^{+}\right)$, and pore water $\mathrm{NH}_{4}^{+}$were determined from cores collected at each site. Equally spaced cores $(n=10-13)$ were collected along a longitudinal transect encompassing one sub reach in DR2 and the entire study reach in Morgan and Maple Creeks.

\section{Surface Water and Pore Water Sampling}

Surface water was collected with ISCO 2900 water samplers (ISCO Environmental, Lincoln, NE) and by hand. Water was pumped through tubing with a $12-\mathrm{V}$ peristaltic pump and filtered in line $(50-\mathrm{mm}$-diameter, $0.45-\mu \mathrm{m}$ membrane filters) into new polyethylene bottles (water samples for total $\mathrm{N}$ 
Table 2. Mean surface-water nutrient concentrations ( $\left.\mathrm{mg} \mathrm{L}^{-1}\right)$.

\begin{tabular}{|c|c|c|c|}
\hline & DR2 Drain, WA & Maple Creek, NE & Morgan Creek, MD \\
\hline $\mathrm{NO}_{3}{ }^{-}-\mathrm{N}$ & $2.9(0.1) \dagger, n=21$ & $0.8(0.3), n=36$ & $2.9(0.2), n=36$ \\
\hline $\mathrm{NH}_{4}^{+}-\mathrm{N}$ & $0.02(0.02), n=12$ & $0.01(0.00), n=36$ & $0.11(0.05), n=36$ \\
\hline DON $\neq$ & $0.35(0.13), n=18$ & $0.72(0.50), n=19$ & $0.75(0.31), n=16$ \\
\hline TN§ & $3.2(0.0), n=10$ & $1.7(0.0), n=13$ & $3.6(0.2), n=12$ \\
\hline DOCף & $2.8(0.1), n=4$ & $4.9(0.9), n=5$ & $5.1(0.6), n=4$ \\
\hline SRP\# & $0.08(0.03), n=18$ & $0.01(0.01), n=19$ & $0.03(0.01), n=16$ \\
\hline TP†† & $0.33(0.24), n=18$ & $0.10(0.03), n=19$ & $0.15(0.02), n=16$ \\
\hline \multicolumn{4}{|c|}{ † Values in parentheses are 1 SD. } \\
\hline \multicolumn{4}{|c|}{ ‡ Dissolved organic nitrogen. } \\
\hline \multicolumn{4}{|c|}{ § Total nitrogen. } \\
\hline \multicolumn{4}{|c|}{ ๆ Dissolved organic carbon. } \\
\hline \multicolumn{4}{|c|}{ \# Soluble reactive phosphorus. } \\
\hline \multicolumn{4}{|c|}{ †† Total phosphorus. } \\
\hline
\end{tabular}

and $\mathrm{P}$ were not filtered). Bottles were pre-rinsed with filtered sample water. Water samples for nutrient analyses were frozen. Stainless steel drive points $(0.64 \mathrm{~cm} \mathrm{ID)}$ ) were installed 0.1 to $1.0 \mathrm{~m}$ deep to collect pore water samples. Water was drawn into the drive points through three slots approximately 0.8 $\mathrm{cm}$ long and $0.04 \mathrm{~cm}$ wide near their pointed base. Pore water (approximately $100 \mathrm{~mL}$ ) was pumped through tubing, filtered in-line, and frozen in a manner analogous to surface water.

\section{Analytical Methods}

Water samples were analyzed for $\mathrm{NO}_{3}^{-}$, nitrite $\left(\mathrm{NO}_{2}^{-}\right)$, $\mathrm{NH}_{4}^{+}$, soluble reactive $\mathrm{P}$, dissolved organic $\mathrm{N}(\mathrm{DON})$, dissolved organic $\mathrm{C}$, $\mathrm{TN}$, total $\mathrm{P}(\mathrm{TP})$, and $\mathrm{Br}^{-}$. Bromide and $\mathrm{NO}_{3}{ }^{-}$were determined on a Dionex DX500 ion chromatograph (Dionex Corporation, Sunnyvale, CA) equipped with an AS4A or AS14 ion-exchange column. Nitrate was also determined on a Bran+Lubbe TrAAcs 800 Continuous Flow Analysis System (Bran+Lubbe, Germany). Ammonium was determined colorimetrically with the Salicylate-Hypochlorite Method (Bower and Holm-Hansen, 1980) or with a Bran+Lubbe TrAAcs 800 Continuous Flow Analysis System. Soluble reactive P was determined colorimetrically by the Molybdenum Blue Method (Fugita, 1969). Dissolved organic $C$ was measured on an Oceanography

Table 3. Photosynthetically active radiation (PAR), chlorophyll $a$, gross primary productivity (GPP), community respiration $\left(\mathrm{CR}_{24}\right)$, and the photosynthesis/respiration ratio ( $\mathrm{P} / \mathrm{R}$ ratio) measured during the 72-h bromide injections.

\begin{tabular}{|c|c|c|c|}
\hline & DR2 Drain, WA & Maple Creek, NE & Morgan Creek, MD \\
\hline Temperature $(C)$ & 15.1 & 23.0 & 23.2 \\
\hline $\mathrm{pH}$ & 7.8 & 8.6 & 7.2 \\
\hline $\operatorname{PAR}\left(\mathrm{mol} \mathrm{m}^{-2} \mathrm{~d}^{-1}\right)$ & $33-39$ & $18-43$ & $4-14$ \\
\hline $\begin{array}{l}\text { Dissolved oxygen } \\
\left(\mathrm{mg} \mathrm{L}^{-1}\right)\end{array}$ & $9.1(89 \%) \dagger$ & $11.4(130 \%)$ & $6.7(77 \%)$ \\
\hline $\begin{array}{l}\text { Chlorophyll } a \\
\left(\mathrm{mg} \mathrm{m}^{-2}\right) \neq\end{array}$ & 1 & 65 & 9 \\
\hline $\operatorname{GPP}\left(\mathrm{g} \mathrm{O}_{2} \mathrm{~m}^{-2} \mathrm{~d}^{-1}\right)$ & 3.2 & 2.4 & 0.4 \\
\hline$C R_{24}\left(g_{2} \mathrm{~m}^{-2} \mathrm{~d}^{-1}\right)$ & -23.2 & -2.0 & -6.0 \\
\hline $\mathrm{P} / \mathrm{R}$ ratio & 0.1 & 1.3 & 0.1 \\
\hline
\end{tabular}

† Values in parentheses are percent saturation

‡ Depositional targeted habitat, USGS NAWQA protocol (Moulton et al., 2002), measured Sept. 2003 (DR2), July 2003 (Maple Creek), and July 2004 (Morgan Creek).
Table 4. Sediment parameters.

DR2 Drain, WA Maple Creek, NE Morgan Creek, MD

\begin{tabular}{|c|c|c|c|}
\hline $\mathrm{pH}$ & $7.67(0.11)+, n=10$ & $8.26(0.04), n=13$ & $6.5(0.09), n=12$ \\
\hline AFDMキ & $22.78(1.85)$ & $1.94(0.06)$ & 23.64 (3.69) \\
\hline TN§ $\left(\mathrm{g} \mathrm{kg}^{-1}\right)$ & $0.56(0.09)$ & $0.07(0.01)$ & $0.72(0.10)$ \\
\hline TOCף $\left(\mathrm{g} \mathrm{kg}^{-1}\right)$ & $5.44(1.11)$ & $0.27(0.02)$ & $7.57(1.2)$ \\
\hline $\mathrm{C} / \mathrm{N}$ (molar) & $10.59(0.82)$ & $5.02(0.43)$ & $12.8(1.72)$ \\
\hline $\begin{array}{l}\text { Exch. } \mathrm{NH}_{4}^{+} \\
\left(\mathrm{mg} \mathrm{N} \mathrm{Led}^{-1}\right) \#\end{array}$ & $5.25(0.55)$ & $0.24(0.03)$ & $4.95(1.51)$ \\
\hline \multicolumn{4}{|c|}{ † Mean ( \pm 1 SD). } \\
\hline \multicolumn{4}{|c|}{ ‡ Ash-free dry mass. } \\
\hline \multicolumn{4}{|c|}{$\S$ Total nitrogen. } \\
\hline \multicolumn{4}{|c|}{ १ Total organic carbon. } \\
\hline
\end{tabular}

International Model $700 \mathrm{C}$ Analyzer (College Station, TX) by persulfate oxidation at high temperature. Nitrate, $\mathrm{NO}_{2}^{-}, \mathrm{NH}_{4}^{+}$, DON, TN, and TP were also determined on selected samples by the US Geological Survey National Water Quality Laboratory.

\section{Results}

\section{Physiochemical Variables}

All studies were conducted during the most biologically active season, usually coincident with low flow. Surface water $\mathrm{NO}_{3}{ }^{-}$concentrations were approximately 1 to $3 \mathrm{mg} \mathrm{N} \mathrm{L}^{-1}$ (Table 2), near the low end of their seasonal range (Puckett et al., 2008). Other $\mathrm{N}$ forms were one to two orders of magnitude lower than $\mathrm{NO}_{3}^{-}$except in Maple Creek, where $\mathrm{NO}_{3}{ }^{-}$and DON were equivalent. Dissolved inorganic $\mathrm{N}$ was the largest fraction of TN in DR2 and Morgan Creek but was $<50 \%$ of TN in Maple Creek. Dissolved organic C ranged from $2.8 \mathrm{mg} \mathrm{L}^{-1}$ at DR2 to $5.1 \mathrm{mg} \mathrm{L}^{-1}$ in Morgan Creek. Surface water concentrations of soluble reactive $\mathrm{P}$, like $\mathrm{NH}_{4}^{+}$, were relatively low among the sites $\left(0.01-0.08 \mathrm{mg} \mathrm{P} \mathrm{L}^{-1}\right)$. Greater than $90 \%$ of TP at Maple Creek was particulate.

Differences among other water quality parameters further suggested that the three streams were dissimilar. Surface water temperatures were lowest at DR2 (Table 3), reflecting ground water, Yakima River irrigation water, and the channel's relatively low width-to-depth ratio. Maple Creek, which had the lowest TN and TP, had the highest $\mathrm{pH}, \mathrm{PAR}, \mathrm{DO}$, percent DO saturation, benthic chlorophyll $a$, and $\mathrm{P} / \mathrm{R}$ ratio, indicating autotrophic dominance.

Sediment characteristics also differed significantly among sites. Benthic sediments ranged from sands in Maple Creek to silts and clays in Morgan Creek. Levels of sediment $\mathrm{pH}$ were markedly different. Maple Creek was the most alkaline, and Morgan Creek was the most acidic (Table 4). Total organic C, TN, AFDM, exchangeable $\mathrm{NH}_{4}^{+}$, and the $\mathrm{C} / \mathrm{N}$ ratio in the sandy Maple Creek sediments were significantly lower than the other sites.

\section{$\mathrm{NO}_{3}$ - Sources and Flow-weighted $\mathrm{NO}_{3}{ }^{-}$Mass Balances}

In DR2, discharge increased from 138 to $145 \mathrm{~L} \mathrm{~s}^{-1}$ over 428 $\mathrm{m}$ (Table 5), and in Maple Creek discharge increased from 362 to $408 \mathrm{~L} \mathrm{~s}^{-1}$ over $1145 \mathrm{~m}$. The absence of surface water tributaries in either reach indicated that ground water increased discharge 
Table 5. Discharge, nitrate $\left(\mathrm{NO}_{3}^{-}\right)$concentration, and $\mathrm{NO}_{3}^{-}$load.

\begin{tabular}{|c|c|c|c|c|c|c|c|c|c|}
\hline & \multicolumn{3}{|c|}{ Discharge } & \multicolumn{3}{|c|}{$\mathrm{NO}_{3}{ }^{-}$concentration } & \multicolumn{3}{|c|}{$\mathrm{NO}_{3}{ }^{-}$load } \\
\hline & DR2 Drain & Maple Creek & Morgan Creek & DR2 Drain & Maple Creek & Morgan Creek & DR2 Drain & Maple Creek & Morgan Creek \\
\hline & \multicolumn{3}{|c|}{$\mathrm{Ls}^{-1}$} & \multicolumn{3}{|c|}{$-\mathrm{mg} \mathrm{N} \mathrm{L}^{-1}$} & \multicolumn{3}{|c|}{$-\mathrm{mg} \mathrm{N} \mathrm{s}^{-1}$} \\
\hline Upstream & 138 & 362 & 197 & 3.1 & 0.9 & 2.6 & 428 & 315 & 504 \\
\hline Ground water & 7 & 46 & $\mathrm{Ab}+$ & $5.3(2.6-6.8)$ & $5.0(0.4-11.7)$ & $10.2(3.9-16.9)$ & 37 & 230 & $204 \ddagger$ \\
\hline Tributaries & $A b \S$ & $A b \S$ & 20 & - & - & - & - & - & 1129 \\
\hline Total $\mathrm{NO}_{3}{ }^{-}$inputs\# & - & - & - & - & - & - & 465 & 545 & 616 \\
\hline Downstream & 145 & 408 & 217 & 3.1 & 0.9 & 2.8 & 444 & 375 & 605 \\
\hline
\end{tabular}

† Ground water discharge through the bed absent (see text).

‡ Estimated ground water load at the floodplain seeps (see text).

$\S$ Tributaries absent.

IT Tributary load is the sum of the $\mathrm{NO}_{3}^{-}$load of 16 surface rivulets plus the $\mathrm{NO}_{3}^{-}$load estimated for the near-stream saturated flow using the average NO3- concentration of the surface rivulets $\left(5 \mathrm{mg} \mathrm{N} \mathrm{L}^{-1}\right)$.

\# Total $\mathrm{NO}_{3}{ }^{-}$inputs = upstream plus ground water (DR2 and Maple Creek) or tributary (Morgan Creek) $\mathrm{NO}_{3}{ }^{-}$inputs.

by 5 and 11\% in DR2 and Maple Creek, respectively. In Morgan Creek, discharge increased from 197 to $217 \mathrm{~L} \mathrm{~s}^{-1}$ (9\%) over 1145 $\mathrm{m}$. A low-permeability clay layer limited direct ground water discharge through the streambed. Rather, ground water discharged from seepage zones at the lateral margins of the near-stream floodplain and then flowed to the stream via small channels or diffuse sheet flow (Puckett et al., 2008). Independent discharge measurements in the larger seep tributaries (Duff, unpublished data, 2007) indicated that approximately $50 \%$ of the lateral discharge increase was in surface rivulets and the remainder in diffuse sheet flow.

Surface water $\mathrm{NO}_{3}{ }^{-}$concentrations were uniform (3.1 $\mathrm{mg} \mathrm{N} \mathrm{L}^{-1}$ ) throughout DR2 (Table 5), although the load increased from 428 to $444 \mathrm{mg} \mathrm{N} \mathrm{s}^{-1}$. Including ground water $\mathrm{NO}_{3}{ }^{-}$load (median ground water concentration of 5.3 mg N L ${ }^{-1}$; range 2.6-6.8 $\mathrm{mg} \mathrm{N} \mathrm{L}^{-1}$ ) (Table 5 and Puckett et al. [2008]), the upstream plus ground water load ( $465 \mathrm{mg} \mathrm{N} \mathrm{s}^{-1}$ ) exceeded the downstream load, indicating retention (Table 5).

Within-reach surface water $\mathrm{NO}_{3}{ }^{-}$concentrations were uniform at Maple Creek and Morgan Creek, although the loads increased along both reaches (Table 5). With the $\mathrm{NO}_{3}{ }^{-}$loads from ground water (Maple Creek) and ground water seeps (Morgan Creek) included, total reach $\mathrm{NO}_{3}{ }^{-}$loads decreased at both sites, again indicating retention as at DR2.

\section{Streambed Exchange and $\mathrm{NO}_{3}-$ Uptake}

None of the $\mathrm{Br}^{-}$added to surface water was observed in 17 drive points installed in DR2 $(15-50 \mathrm{~cm}$ deep) after $70 \mathrm{~h}$ of addition, indicating minimal penetration into the bed.

Of 30 drive points installed in Maple Creek $(10-46 \mathrm{~cm}$ deep), eight received $\mathrm{Br}^{-}$during the addition. There was no relationship between $\mathrm{Br}^{-}$concentration and depth except that drive points at $>20 \mathrm{~cm}$ lacked $\mathrm{Br}^{-}$tracer. The ratio of $\mathrm{Br}^{-}$increase in the drive points to $\mathrm{Br}^{-}$increase in the channel represents the percent stream water composition in pore water at that point (Triska et al., 1993). The percent stream water in drive points receiving $\mathrm{Br}^{-}$ranged from 3 to $100 \%$ and averaged 39\%. The median $\mathrm{NO}_{3}{ }^{-}$concentration in drive points that received $\mathrm{Br}^{-}$was $0.02 \mathrm{mg} \mathrm{N} \mathrm{L}^{-1}$ (range, $<0.01-0.10 \mathrm{mg} \mathrm{N} \mathrm{L}^{-1}$ ) and ranged from $<1$ to $93 \%$ of the $\mathrm{NO}_{3}^{-}$predicted by $\mathrm{Br}^{-}$, assuming its conservative transport with surface water. Because average ground water
$\mathrm{NO}_{3}^{-}$concentration was significantly higher than surface water (5.0 vs. $0.9 \mathrm{mg} \mathrm{N} \mathrm{L}^{-1}$ ), <5\% of ground water $\mathrm{NO}_{3}^{-}$was present in the $\mathrm{Br}^{-}$-receiving drive points, indicating nearly complete $\mathrm{NO}_{3}{ }^{-}$loss during ground water transport.

Ten of 34 drive points contained $>1 \%$ stream water in Morgan Creek and averaged 26\% surface water. Drive point depths ranged from 10 to $96 \mathrm{~cm}$, but only one receiving $\mathrm{Br}^{-}$ was $>20 \mathrm{~cm}$ deep. The median $\mathrm{NO}_{3}{ }^{-}$concentration in these drive points was $0.03 \mathrm{mg} \mathrm{N} \mathrm{L}^{-1}$ (range, $0.01-2.8 \mathrm{mg} \mathrm{N} \mathrm{L}^{-1}$ ) and was $<1$ to $36 \%$ of the $\mathrm{NO}_{3}{ }^{-}$predicted by $\mathrm{Br}^{-}$assuming conservative transport with surface water.

\section{Transient Storage Modeling}

At DR2, the storage cross-sectional area was approximately 0.03 the size of channel cross-sectional area $\left(\mathrm{A}_{\mathrm{s}} / \mathrm{A}\right)$, and the storage residence time $\left(t_{\text {sto }}\right)$ was approximately $5 \mathrm{~min}$ (Table 6). At Maple and Morgan Creek, the cross-sectional areas of storage were approximately 0.1 of channel cross-sectional areas, and the storage times were slightly longer (approximately $7-8 \mathrm{~min}$ ). Solute residence time in the storage zone was positively correlated with the travel time among sites $\left(r^{2}=0.83\right)$. The fraction of median travel time due to transient storage $\left(F_{\text {med }}{ }^{200}\right)$ in DR2 was 0.008 , indicating that the average solute molecule spent $<1 \%$ of its time in storage. Low $F_{\text {med }}{ }^{200}$ values were also observed in Maple and Morgan Creek where solute molecules spent just 1 to $2 \%$ of their time in storage. The reach-averaged depths of the storage zones were 3.0 to $3.9 \mathrm{~cm}$.

\section{Nitrification, Denitrification, and $\mathrm{NO}_{3}-$ Uptake Rates}

Average nitrification and denitrification potentials measured in sediment slurries ranged from 1.6 to 4.4 and 2.1 to

Table 6. Transport metrics from bromide tracer data and OTIS-P simulations.

\section{DR2 Drain, WA Maple Creek, NE Morgan Creek, MD}

\begin{tabular}{llll}
\hline Travel time $(\mathrm{min})$ & 40 & 62 & 100 \\
$A_{\mathrm{s}} / A$ & 0.03 & 0.13 & 0.07 \\
$F_{\text {med }} 200$ & 0.008 & 0.017 & 0.018 \\
$t_{\text {sto }}+(\mathrm{min})$ & 4.8 & 7.4 & 8.3 \\
$d_{\text {sto }} \neq(\mathrm{cm})$ & 3.0 & 3.9 & 3.4 \\
\hline
\end{tabular}

† Solute residence time in storage zone $\left(A_{5} A^{-1} \mathrm{a}^{-1}\right)$.

‡ Storage zone depth. 

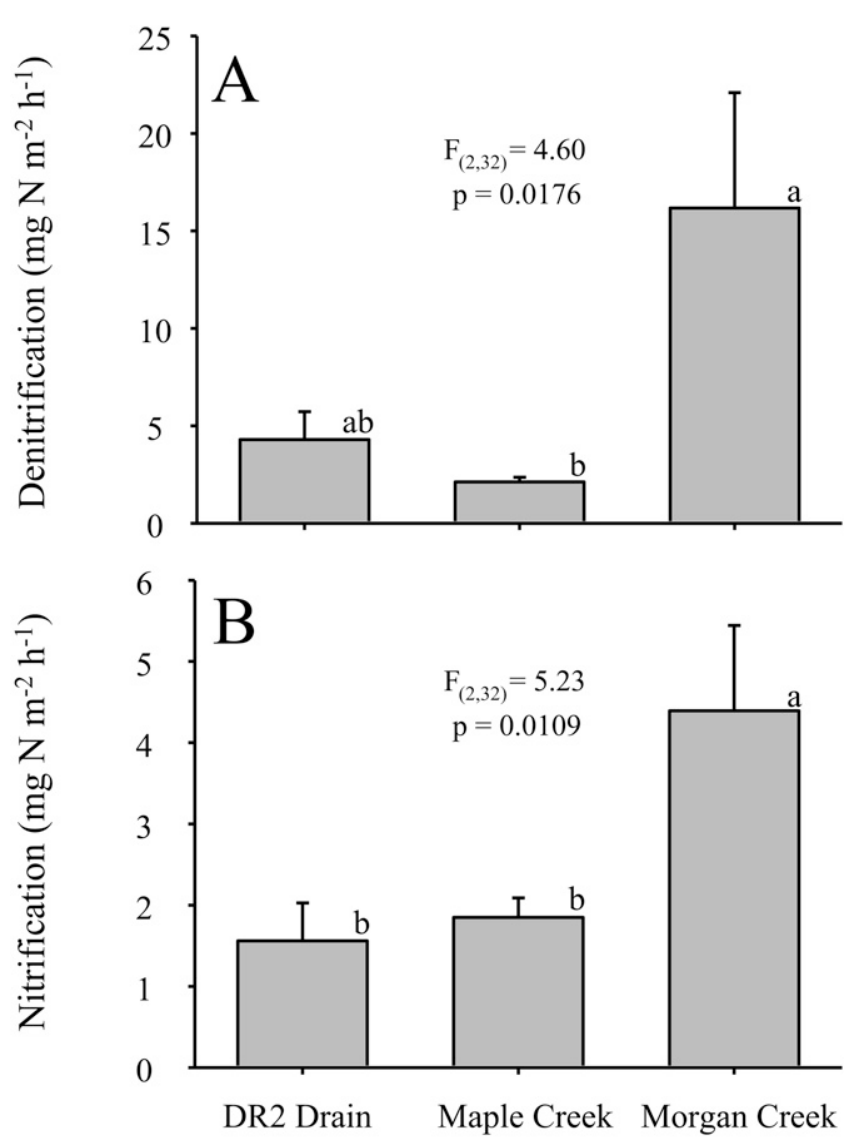

Fig. 1. Mean denitrification (A) and nitrification (B) rates measured in sediment samples from DR2, Maple Creek, and Morgan Creek. One-way ANOVA statistics are shown in each panel. Bars with different lowercase letters indicate significant differences between mean values. Error bars indicate $\pm 1 \mathrm{SE}$.

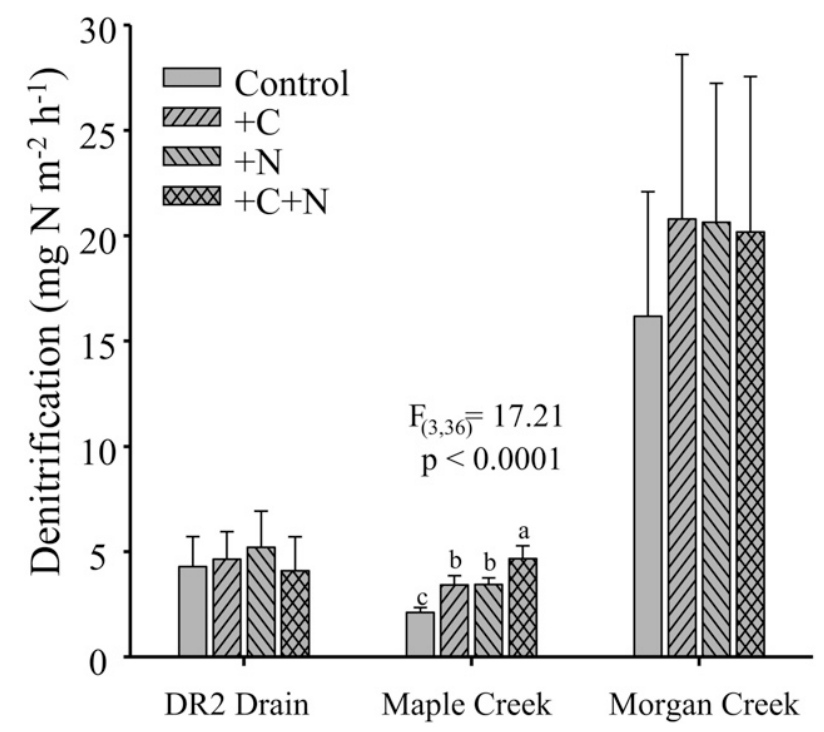

Fig. 2. Mean denitrification response in sediments from DR2, Maple Creek, and Morgan Creek to no amendment (Control) and amendments of $12 \mathrm{mg} \mathrm{CL} \mathrm{L}^{-1}$ as glucose $(+\mathrm{C}), 14 \mathrm{mg} \mathrm{N} \mathrm{L}^{-1}$ as $\mathrm{NO}_{3}^{-}(+\mathrm{N})$, and glucose $+\mathrm{NO}_{3}{ }^{-}(+\mathrm{C}+\mathrm{N})$. One-way ANOVA statistics are shown for Maple Creek (differences among means at other sites were not significant). Bars with different lowercase letters indicate significant differences between mean values. Error bars indicate $\pm 1 \mathrm{SE}$.
$16.2 \mathrm{mg} \mathrm{N} \mathrm{m}^{-2} \mathrm{~h}^{-1}$, respectively, among the sites (Fig. 1). Morgan Creek had the highest potential rates for nitrification and denitrification, highest stream water $\mathrm{NO}_{3}{ }^{-}$concentration at the time of the assays (Richardson, unpublished data, 2007), highest temperature, and highest $\mathrm{N}$ and $\mathrm{C}$ content in sediment (Table 4).

Maple Creek was the only site where nutrient amendments significantly increased denitrification potential (Fig. 2). Maple Creek had an ambient surface water $\mathrm{NO}_{3}{ }^{-}$concentration of 0.6 $\mathrm{mg} \mathrm{N} \mathrm{L}{ }^{-1}$ on the day the experiments were performed. Nitrate and glucose amendments equally increased denitrification rates. The denitrification response to the $\mathrm{N}+\mathrm{C}$ treatment exceeded the response to individual treatments, suggesting co-limitation. These results are consistent with the low levels of denitrification substrates (TN, TOC, and AFDM) observed in the sediments. Similar temperature in Maple Creek and Morgan Creek and lower nutrientamended rates in Maple Creek than unamended rates in Morgan Creek suggested that the denitrifying community and extant pool of denitrification enzymes was poorly established in Maple Creek.

Nitrate was consumed under background conditions in benthic sediment enclosures at Maple Creek (Fig. 3). The $\mathrm{NO}_{3}{ }^{-} / \mathrm{Br}^{-}$ratios decreased from 0.31 to 0.18 during $8-\mathrm{h}$ incubations, for a $\mathrm{NO}_{3}{ }^{-}$removal rate of $5.1 \mathrm{mg} \mathrm{N} \mathrm{m}^{-2} \mathrm{~h}^{-1}$ (Duff, unpublished data, 2007). In Morgan Creek, there was a small but statistically insignificant increase in $\mathrm{NO}_{3}^{-} / \mathrm{Br}^{-}$ ratio in the enclosures, suggesting $\mathrm{NO}_{3}{ }^{-}$release, whereas in $\mathrm{DR} 2$ the $\mathrm{NO}_{3}^{-} / \mathrm{Br}^{-}$ratios remained uniform.

\section{Pore Water Nutrient Patterns}

In DR2 and Morgan Creek, pore water $\mathrm{NH}_{4}^{+}$concentrations were higher in drive points $<20 \mathrm{~cm}$ deep than in deeper drive points (Fig. 4A). Concentrations as high as $5 \mathrm{mg} \mathrm{N} \mathrm{L}^{-1}$ in Morgan Creek and $3.5 \mathrm{mg} \mathrm{N} \mathrm{L}^{-1}$ in DR2 imply significant mineralization of organic matter, consistent with elevated sediment $\mathrm{C}$ and $\mathrm{N}$ levels. Pore water $\mathrm{NO}_{3}{ }^{-}$levels were generally low in both streams (Fig. $4 \mathrm{~B})$. High $\mathrm{NO}_{3}{ }^{-}$concentrations observed in drive points 90 to $100 \mathrm{~cm}$ deep in Morgan Creek were isolated under the clay lense. Three shallow drive points with high $\mathrm{NO}_{3}{ }^{-}$in Morgan Creek presumably indicated pockets of high nitrification. In Maple Creek, pore water $\mathrm{NO}_{3}{ }^{-}$concentrations were 1 to $12 \mathrm{mg} \mathrm{N} \mathrm{L}^{-1}$ in most drive points (average, 2.6; median, 0.18; range, 0-11.7 $\mathrm{mg} \mathrm{N} \mathrm{L}^{-1}$ ).

\section{Metabolism}

Maple Creek surface water had the largest variation of diurnal $\mathrm{NO}_{3}{ }^{-} / \mathrm{Br}^{-}$ratios, and Morgan Creek had the smallest (Fig. 5). The difference between low and high $\mathrm{NO}_{3}{ }^{-} / \mathrm{Br}^{-}$ratios in Maple Creek was 0.63, with the lowest ratio at 1800 and highest ratio at 0600 (Fig. 5), indicating photosynthetic $\mathrm{NO}_{3}{ }^{-}$demand. In contrast, the difference between low and high $\mathrm{NO}_{3}{ }^{-} / \mathrm{Br}^{-}$ratios in Morgan Creek, which is the heavily shaded and turbid stream, was only 0.12 , with low and highs inversely related to the typical photosynthetic period. Diurnal variation in DR2 was 0.28 , with low and high ratios corresponding to photosynthetic periods.

Dissolved oxygen, $\mathrm{pH}$, and $\mathrm{NO}_{3}{ }^{-}$in surface water varied diurnally at Maple Creek (Fig. 6), with DO maxima preceding the 
$\mathrm{NO}_{3}^{-}$minima in late afternoon. Diurnally, DO varied by $4 \mathrm{mg} \mathrm{L}^{-1}$, and $\mathrm{NO}_{3}{ }^{-}$varied by approximately $0.5 \mathrm{mg} \mathrm{N} \mathrm{L}^{-1}$. Although the average gross primary productivity was 1.3 to 8.3 times higher in DR2 than Maple Creek and Morgan Creek, respectively, community respiration was 11.4 times higher at DR2 than Maple Creek, resulting in a P/R ratio significantly $<1$ (Table 3 ). The $\mathrm{P} / \mathrm{R}$ ratio equaled 1.3 in Maple Creek, indicating a net autotrophic site.

\section{Discussion}

\section{Ground Water Discharge}

The capacity of a stream to process high $\mathrm{NO}_{3}^{-}$ loads results from the interplay between hydrologic and bed sediment properties that determine hydraulic conductivity and porosity, the capacity for ground water and surface water to deliver nutrients to microbial communities, water residence time, and biotic-processing potential. The gradient between ground water and surface water determines the direction of water flow through the streambed and hence the potential to process surface water $\mathrm{NO}_{3}{ }^{-}$relative to that in ground water discharge. This study found a potential for $\mathrm{NO}_{3}^{-}$retention during ground water and surface water transport, although ground water $\mathrm{NO}_{3}{ }^{-}$retention overwhelmingly dominated surface water via potential denitrification and assimilatory uptake. Once in surface water, the channel's capacity for $\mathrm{NO}_{3}{ }^{-}$retention was greatly diminished.

Ground water discharged directly through the bed at DR2 and Maple Creek. It was approximately 6.5 times higher in Maple Creek than DR2, but due to greater reach length, net ground water discharge rate was only 2.5 times higher $(0.04$ vs. $0.016 \mathrm{~L}$ $\left.\mathrm{s}^{-1} \mathrm{~m}^{-1}\right)$. Our calculated discharge magnitudes from the water balances were consistent with Essaid et al. (2008) and Puckett et al. (2008), who found vertical hydraulic conductivity of streambed sediments and ground water velocities 6 to 60 times greater in Maple Creek than DR2. At Morgan Creek, where ground water entered via lateral riparian surface flows, the net ground water discharge rate was similar to DR2 $\left(0.017 \mathrm{~L} \mathrm{~s}^{-1} \mathrm{~m}^{-1}\right)$.

Nitrate input in ground water varied among sites. Approximately $8 \%$ of the gross $\mathrm{NO}_{3}{ }^{-}$input to the reach in DR2 (0.09 $\mathrm{mg} \mathrm{N} \mathrm{s}^{-1} \mathrm{~m}^{-1} ; \mathrm{C}_{L(\text { gross })} ;$ Table 7$)$ and $42 \%$ in Maple Creek $(0.20$

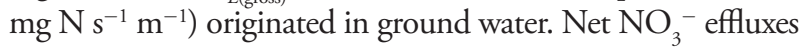
from the streambeds were 0.04 and $0.05 \mathrm{mg} \mathrm{N} \mathrm{s}^{-1} \mathrm{~m}^{-1}\left(\mathrm{C}_{L \text { (net); }}\right.$ Table 7). Excluding streambed nitrification, approximately $60 \%$ of the gross ground water $\mathrm{NO}_{3}{ }^{-}$load to DR2 and $75 \%$ to Maple Creek was retained in the bed. Streambed nitrification potentially accounted for an additional 2 to $11 \%$ of net $\mathrm{NO}_{3}{ }^{-}$efflux to DR2 and Maple Creek, respectively (Table 7). Although nitrification rates were similar in DR2 and Maple Creek (1.6 and $1.8 \mathrm{mg}$ $\mathrm{N} \mathrm{m}^{-2} \mathrm{~h}^{-1}$; Fig. 1), the potential addition of $\mathrm{NO}_{3}{ }^{-}$mass was approximately 7 times higher in Maple Creek than in DR2 (0.0056 vs. $0.0008 \mathrm{mg} \mathrm{N} \mathrm{m}^{-1} \mathrm{~s}^{-1}$; Table 7) because the streambed surface area in Maple Creek was approximately 15 times larger. Denitrification rates exceeded nitrification rates at all sites, suggesting

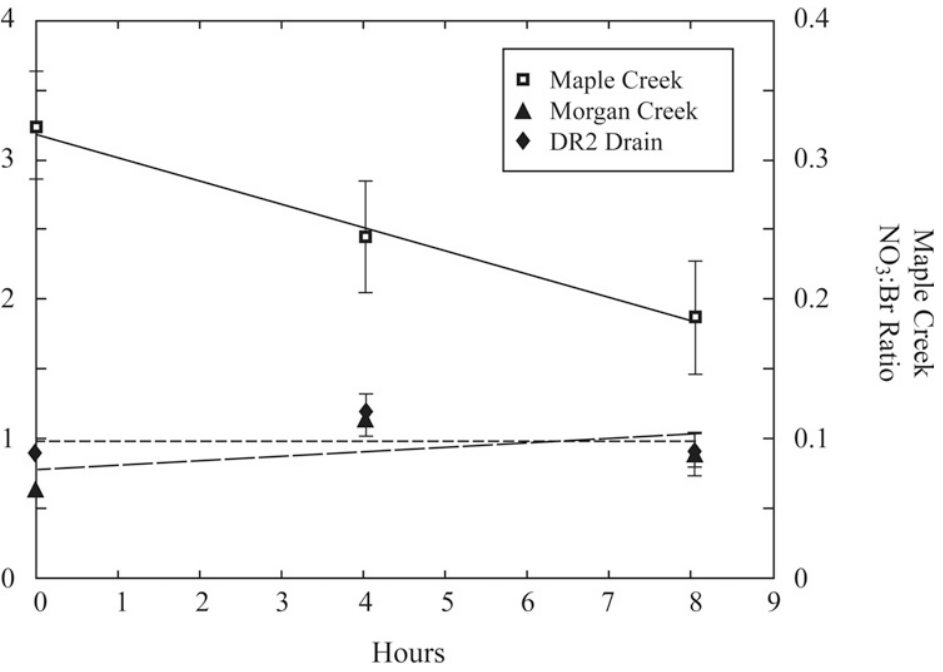

( the streambed for $8 \mathrm{~h}$ at DR2 $(n=5)$, Maple Creek $(n=5)$, and Morgan Creek $n=11)$. Error bars indicate $1 \mathrm{SE}$.

little net nitrification impact on surface water $\mathrm{NO}_{3}{ }^{-}$loads. Approximately $30 \%$ of the gross $\mathrm{NO}_{3}{ }^{-}$inputs in Morgan Creek were associated with adjacent ground water seeps (calculated from Table 5). Approximately $55 \%$ of the gross ground water $\mathrm{NO}_{3}{ }^{-}$load reached the channel via overland riparian flows. The net contribution by ground water to the $\mathrm{NO}_{3}^{-}$load per meter stream length was highest among the sites $(0.09 \mathrm{mg}$

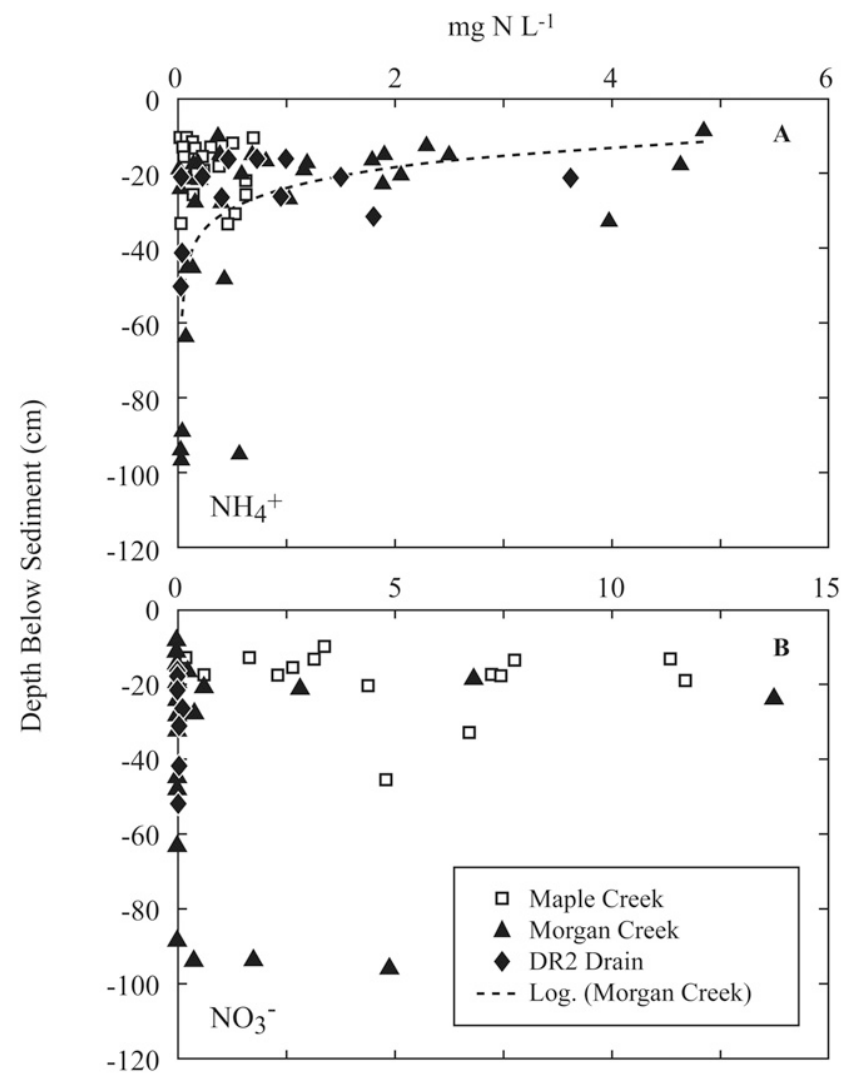

Fig. 4. (A) Ammonium $\left(\mathrm{NH}_{4}^{+}\right)$and (B) nitrate $\left(\mathrm{NO}_{3}^{-}\right)$concentrations in drive points at DR2, Maple Creek, and Morgan Creek. 


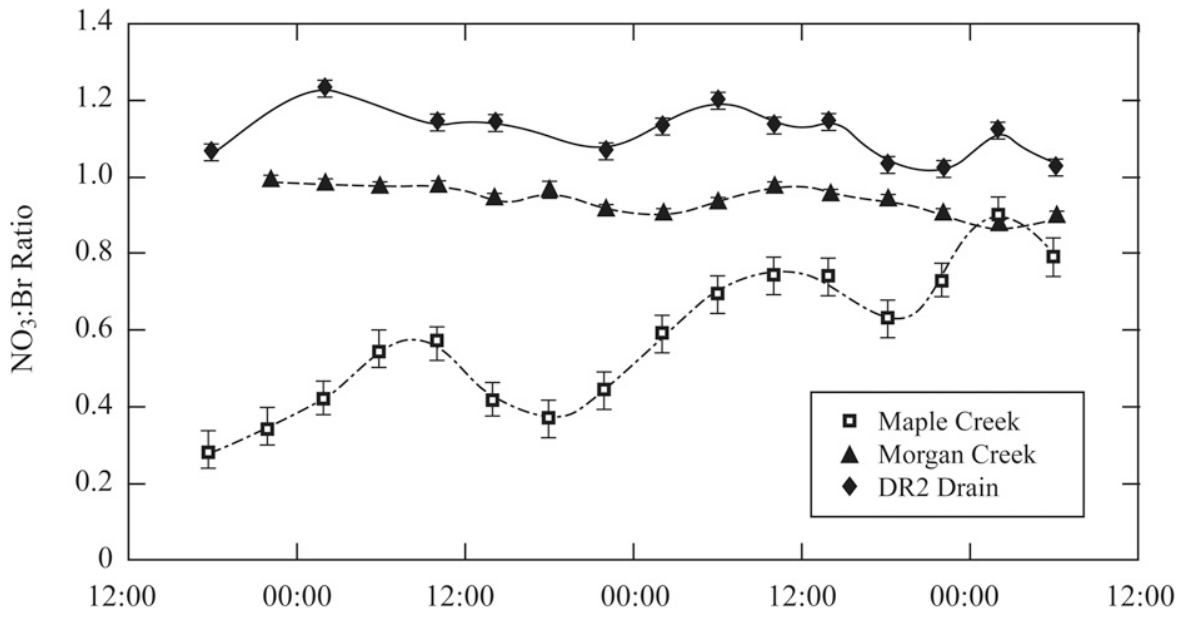

Fig. 5. Diurnal nitrate-N/bromide ratios $\left(\mathrm{NO}_{3}{ }^{-} / \mathrm{Br}^{-}\right)$in stream water at $\mathrm{DR2}$, Maple Creek, and Morgan Creek. Data were collected at three or four stations. Error bars indicate $\pm 1 \mathrm{SE}$.

$\mathrm{N} \mathrm{s}^{-1} \mathrm{~m}^{-1} ; \mathrm{C}_{L(\text { net }} ;$ Table 7). Forty-five percent of ground water $\mathrm{NO}_{3}{ }^{-}$was retained in organic-rich seep discharge zones or in the rivulets. Nitrate retention was on par with direct ground water discharge through the bed at the other sites.

After adjusting for $\mathrm{NO}_{3}{ }^{-}$retention, net $\mathrm{NO}_{3}{ }^{-}$release in discharging ground water contributed 4 to $16 \%$ of the combined upstream plus ground water $\mathrm{NO}_{3}{ }^{-}$loads. This contribution represented $1.4,5.2$, and $8.6 \mathrm{~kg} \mathrm{~N} \mathrm{~d}^{-1}$ that was exported from DR2, Maple Creek, and Morgan Creek, respectively.

\section{Surface Water Exchange}

The extent of mixing between surface water and ground water varies by catchment and even within reaches. In catchments with high alluvial conductivity, streambed slope variation, and relatively low ground water pressure gradients, surface water penetration into the streambed may be large, with pore water consisting almost entirely of stream water. In this case, retention associated with downwelling can significantly affect solute composition and concentration in subsurface flowpaths and return flows (Triska et al., 1989;
Valett et al., 1990; Jones et al., 1995). Conversely, large upward ground water pressure gradients or fine bed sediments restrict surface water penetration (Hill and Lymburner, 1998), and shallow pore water consists primarily of ground water. With low storage zone cross-sectional area and short solute storage time, the retention associated with surface water penetration is significantly reduced, and nutrient transformations may be largely associated with ground water (Hinkle et al., 2001).

Puckett et al. (2008) found that hydrogeologic controls limited or even prevented surface water infiltration at DR2. Their analysis of hydrologic head in the stream channel and surrounding ground water indicated potential discharge of shallow and deep ground water but not for surface water penetration into the bed. One-dimensional vertical models of water and heat flow, which estimated ground water-surface water fluxes through the bed, suggested that DR2 always gains water (Essaid et al., 2008), similar to our $\mathrm{Br}^{-}$tracer study. Based on $\mathrm{Br}^{-}$ analyses in 17 drive points, none had elevated $\mathrm{Br}^{-}$even after $72 \mathrm{~h}$ of addition. In contrast, 27 to 29\% of the drive points in Maple Creek and Morgan Creek had elevated $\mathrm{Br}^{-}$levels. These drive points averaged 39\% stream water penetration to the bed at Maple Creek and 26\% at Morgan Creek. Puckett et al. (2008) observed generally positive streambed heads in Maple Creek, although some reversals were noted during storms. Their flow directions based on equipotential lines indicated that pore water was dominated by ground water. This was confirmed at most of the drive points we installed over reaches 2 to 3 times longer and across a wider grid. However, the increased spatial coverage indicated zones of active recharge and discharge. This is not surprising given the coarse sand sediments and large vertical hydraulic conductivities in Maple Creek. In Morgan Creek, however, low upward-flow velocity ef-

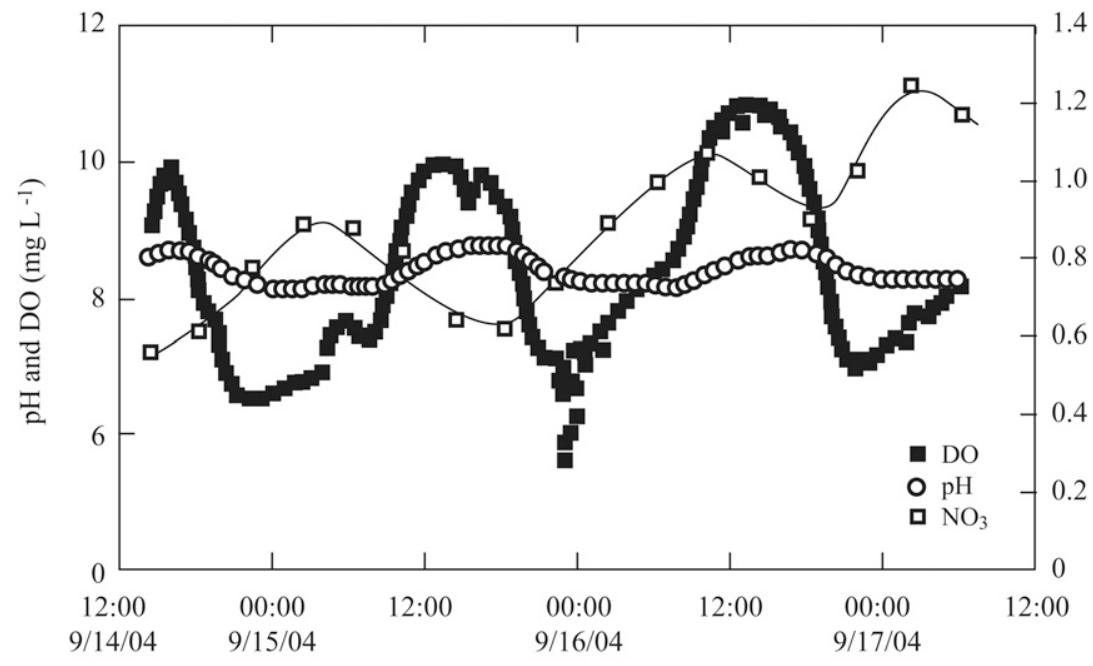

Fig. 6. Diurnal patterns of $\mathrm{pH}$, dissolved oxygen (DO), and nitrate $\left(\mathrm{NO}_{3}^{-}\right)$in stream water at Maple Creek. Data were collected at three or four stations. Error bars are smaller than the symbols. fectively eliminated direct ground water discharge (Puckett et al., 2008), favoring surface water penetration into the bed. Morgan Creek also differed in that it had a well developed riparian canopy, so large woody debris was common in the channel. Large woody debris forms organic dams that obstruct stream flow (Bilby, 1981; Hale and Groffman, 2006) and facilitate head distributions, favoring surface water penetration (Gooseff et al., 2007).

Two widely used parameters to assess the significance of transient storage in streams are the cross-sectional area of the storage zone and the cross-sectional area of the stream. The cross-sectional area of storage was approximately 0.03 times the size of the stream cross-sectional area in DR2 $(A / A)$ and approximately 0.1 times 
the stream cross-sectional area in Maple and Morgan Creek. Values of $A / A$ for Maple and Morgan Creek, both third- and fourth-order low-gradient streams, were comparable to similar size streams in North Carolina (D’Angelo et al., 1993). They were also similar to West Fork Walker Branch in Tennessee (Mulholland et al., 1997) but generally lower than Gallina Creek in New Mexico (Morrice et al., 1997), Little Lost Man Creek in California (Bencala, 1984), the Snake River in Colorado (Bencala et al., 1990), and St. Kevin Gultch in Colorado (Broshears et al., 1993), all of which are high-gradient streams. The $A / A$ value from DR2 is among the lowest published values from the same streams (Runkel, 2002). Low $A / A$ values suggest that low gradient and high surface water and ground water discharge associated with these agricultural streams restricted surface water exchange with the bed compared with high-gradient, first-order streams. In DR2, where the channel intercepts the water table, upward hydraulic gradients further limited the size of the storage zone.

Runkel (2002) found that $A / s$ alone is not the best gauge to determine the significance of transient storage. He suggested an alternative metric, $F_{\text {med }}{ }^{200}$, which is the fraction of the median travel time that a molecule of conservative tracer spends in the transient storage zone. The $F_{\text {med }}{ }^{200}$ values were 6 times lower at DR2 than at Maple Creek and Morgan Creek (0.003 versus 0.017 and 0.018). In DR2, water in transport spent an average of approximately $0.1 \%$ of its time in storage. The very low $F_{\text {med }}{ }^{200}$ at DR2 reflected its linear engineered geomorphology, which included low gradient and fine-grained sediments. Channelization reduces diversity in velocity and substrate conditions that can diminish transient storage and $\mathrm{N}$ retention (Bukaveckas, 2007). DR2 also lacked the natural woody debris that promotes exchange and forms potential "hotspots" for hyporheic nutrient cycling (Hale and Groffman, 2006). The $F_{\text {med }}{ }^{200}$ for Maple Creek and Morgan Creek were higher but fell in the lower $25 \%$ of $F_{\text {med }}{ }^{200}$ values summarized in Runkel (2002). In Maple and Morgan Creek, water was transiently stored in the hyporheos an average of approximately $1 \%$ of its time. Even though the mean time in storage was low, the coarse sands in Maple Creek and prominent bed features in Morgan Creek facilitated some surface water penetration into the bed.

\section{Nitrification, Denitrification, and $\mathrm{NO}_{3}^{-}$Uptake}

Rates of sediment nitrification tend to be higher in agriculturally dominated than in pristine streams (Kemp and Dodds, 2002; Strauss et al., 2004) probably because of the long-term N loading and accumulation in ground water. Measured nitrification rates ranged from 1.6 to $4.4 \mathrm{mg} \mathrm{N} \mathrm{m}^{-2} \mathrm{~h}^{-1}$, which is 1.5 to 4.5 times higher than rates reported for a survey of 42 streams in the USA (Strauss, 2000) and 1.5 to 3.0 times lower than the median for $\mathrm{NH}_{4}^{+}$-enriched sediments in the Upper Mississippi River (Strauss et al., 2004). Significant factors affecting nitrification rates include DO, temperature, and exchangeable $\mathrm{NH}_{4}^{+}$(Kemp and Dodds, 2001; Strauss et al., 2004). Significantly higher nitrification rates in Morgan Creek sediments corresponded to higher concentrations of pore water and exchangeable $\mathrm{NH}_{4}^{+}$. A positive relationship between sediment nitrification and $\mathrm{NH}_{4}^{+}$availability is common (Triska et al., 1990; Jones et al., 1995; Strauss et al., 2002), particularly in environments like Morgan Creek where $\mathrm{C} / \mathrm{N}$ ratios $<20$
Table 7. Nitrate $\left(\mathrm{NO}_{3}{ }^{-}\right)$loss rates in ground water discharge.

DR2 Drain, WA Maple Creek, NE Morgan Creek, MD

\begin{tabular}{|c|c|c|c|}
\hline \multirow[b]{2}{*}{$C_{L(\text { gross })} \dagger$} & \multicolumn{3}{|c|}{$-\mathrm{mg} \mathrm{N} \mathrm{s}^{-1} \mathrm{~m}^{-1}$} \\
\hline & 0.09 & 0.20 & $A b \neq$ \\
\hline$C_{L(\text { net) }} \S$ & 0.04 & 0.05 & 0.09 \\
\hline $\mathrm{NO}_{3}^{-}$Ret 9 & 0.05 & 0.15 & 0.01 \\
\hline $\begin{array}{l}\text { Nitrification } \\
\text { rate\# }\end{array}$ & 0.001 & 0.006 & 0.005 \\
\hline $\begin{array}{l}\text { Denitrification } \\
\text { rate\# }\end{array}$ & 0.002 & 0.006 & 0.019 \\
\hline \multicolumn{4}{|c|}{ T The gross $\mathrm{NO}_{3}^{-}$flux in ground water discharge. } \\
\hline \multicolumn{4}{|c|}{ \# Ground water discharge through the bed absent (see text). } \\
\hline \multicolumn{4}{|c|}{$\S$ The net $\mathrm{NO}_{3}^{-}$efflux from the bed to surface water. } \\
\hline \multicolumn{4}{|c|}{ If Net streambed $\mathrm{NO}_{3}{ }^{-}$retention rates $\left(C_{L \text { (gross) }}-C_{L \text { (net) }}\right)$. } \\
\hline
\end{tabular}

enable nitrifiers to out compete heterotrophs for $\mathrm{NH}_{4}^{+}$(Strauss et al., 2002). Streambed nitrification potentially accounted for 2 to $11 \%$ of the net increase in upstream-downstream $\mathrm{NO}_{3}{ }^{-}$. However, higher denitrification than nitrification rates at all sites suggest little net nitrification impact on $\mathrm{NO}_{3}{ }^{-}$flux from the bed due to concurrent nitrification and denitrification.

Nitrate availability is a dominant predictor of sediment denitrification rates (Inwood et al., 2005). The elevated $\mathrm{NO}_{3}{ }^{-}$concentrations in surface water and ground water likely facilitated denitrification at our sites. Our unamended denitrification rates, ranging from 2.0 to $16.3 \mathrm{mg} \mathrm{N} \mathrm{m}^{-2} \mathrm{~h}^{-1}$, were high compared with most streams (Seitzinger, 1988) but were comparable to denitrification rates (acetylene block) in five agricultural streams in Illinois (up to $15 \mathrm{mg} \mathrm{N} \mathrm{m}^{-2} \mathrm{~h}^{-1}$; Royer et al., 2004). Our measurements were also comparable to denitrification estimates made in cores using membrane inlet and isotope ratio mass spectrometry in two Illinois streams $\left(4.6-6.9 \mathrm{mg} \mathrm{N} \mathrm{m}^{-2} \mathrm{~h}^{-1}\right.$; Smith et al., 2006), to estimates made using changes in dissolved $\mathrm{N}_{2}$ concentrations to measure denitrification of surface water $\mathrm{NO}_{3}{ }^{-}$(Laursen and Seitzinger, 2002), and to estimates made using changes in ${ }^{15} \mathrm{~N}_{2}$ in ${ }^{15} \mathrm{~N}^{-\mathrm{NO}_{3}}{ }_{3}^{-}$-enriched stream water (Böhlke et al., 2004).

We analyzed pore water nutrients to characterize the potential for coupled nitrification-denitrification. Nitrate and $\mathrm{NH}_{4}^{+}$ data from 81 drive points suggested nitrification-denitrification may have been coupled at DR2 and Morgan Creek but not at Maple Creek where pore water $\mathrm{NH}_{4}^{+}$concentrations were low and $\mathrm{NO}_{3}{ }^{-}$concentrations were already high. Pore water $<20 \mathrm{~cm}$ deep at DR2 and Morgan Creek had high $\mathrm{NH}_{4}^{+}$and low but measurable $\mathrm{NO}_{3}{ }^{-}$, suggesting that nitrification was a potential $\mathrm{NO}_{3}{ }^{-}$source for denitrification. High $\mathrm{NH}_{4}^{+}$and low $\mathrm{NO}_{3}{ }^{-}$also suggested that the pore water environment was strongly reduced, which would limit nitrification. Pore water $\mathrm{O}_{2}$ data from Puckett et al. (2008) generally supported this assumption. Median streambed DO was $<0.02 \mathrm{mg} \mathrm{L}^{-1}$ at DR2 (range, 0-6.4 $\mathrm{mg} \mathrm{L}^{-1}$ ) and $2.8 \mathrm{mg} \mathrm{L}^{-1}$ at Morgan Creek (range, $0-11.4 \mathrm{mg} \mathrm{L}^{-1}$ ). In addition, denitrification of surface water $\mathrm{NO}_{3}{ }^{-}$was not limited by $\mathrm{NO}_{3}{ }^{-}$availability in the enzyme assays at DR2 or Morgan Creek, suggesting that denitrification can precede independent of nitrification.

Maple Creek was the only site with a $\mathrm{P} / \mathrm{R}$ ratio $>1$, indicating net photosynthesis. In addition, $\mathrm{pH}, \mathrm{DO}, \mathrm{DO}$ saturation, benthic 
chlorophyll $a$, and PAR were significantly higher there. Nitrate, $\mathrm{DO}, \mathrm{pH}$, and $\mathrm{NO}_{3}{ }^{-} / \mathrm{Br}^{-}$ratio had strong diurnal patterns, suggesting uptake of inorganic nutrients. The $\mathrm{NO}_{3}{ }^{-}$removal rate in benthic enclosures presumably associated with assimilatory demand was $5.1 \mathrm{mg} \mathrm{N} \mathrm{m}^{-2} \mathrm{~h}^{-1}$, approximately 2.5 times higher than denitrification potentials (Fig. 3 and Duff, unpublished data, 2007). The combined effects of high nutrients, open canopy, and high stream water temperature at Maple Creek resulted in dissolved $\mathrm{N}$ uptake dominated by photoautotrophic assimilation.

\section{$\mathrm{NO}_{3}-$ Retention in Ground Water}

Evidence from this study, Puckett et al. (2008), and Essaid et al. (2008) suggests a higher potential for ground water discharge or shallow lateral inflow than penetration of surface water into the bed at DR2. Our $\mathrm{NO}_{3}{ }^{-}$loss calculations indicated that approximately $60 \%$ of the $\mathrm{NO}_{3}{ }^{-}$load in ground water was retained in the bed (Table 7). Using the reach-scale sediment denitrification rate measured in the top $5 \mathrm{~cm}$ of sediment $\left(0.002 \mathrm{mg} \mathrm{N} \mathrm{s}^{-1} \mathrm{~m}^{-1}\right)$ as a proxy, denitrification could account for approximately $5 \%$ of the $\mathrm{NO}_{3}{ }^{-}$loss in ground water $\left(0.05 \mathrm{mg} \mathrm{N} \mathrm{s}^{-1} \mathrm{~m}^{-1}\right)$. Ground water would need to pass through approximately $1 \mathrm{~m}$ of sediment to account for the observed $\mathrm{NO}_{3}{ }^{-}$loss if our measured rate was representative throughout the reach. At DR2, however, most ground water may have entered in shallow lateral flows (Puckett et al., 2008) where $\mathrm{NO}_{3}{ }^{-}$might encounter higher denitrification rates in small seepage flows.

In Maple Creek, we estimated that approximately $75 \%$ of the $\mathrm{NO}_{3}{ }^{-}$load in ground water was retained in the bed (Table 7). Again, streambed denitrification measured in the top $5 \mathrm{~cm}$ of sediment could account for only approximately $5 \%$ of the $\mathrm{NO}_{3}{ }^{-}$loss. This was not surprising because of the low sediment $\mathrm{C}$ and limited pool of denitrifying enzymes. Sediment denitrification rates also decrease with depth (Sheibley et al., 2003; Sheibley et al., 2006), so it is unlikely that sediments deeper than $5 \mathrm{~cm}$ supported significant denitrification as demonstrated by high pore water $\mathrm{NO}_{3}{ }^{-}$. Low denitrification potentials and high autotrophic demand likely indicated that $\mathrm{NO}_{3}{ }^{-}$in discharging ground water at Maple Creek was assimilated by the thin layer of benthic diatoms, a scenario similar to Sycamore Creek, AZ (Valett et al., 1996).

Nitrate retention in ground water discharge adjacent to Morgan Creek was on par with direct ground water discharge through the bed at DR2 and Maple Creek. Forty-five percent of ground water $\mathrm{NO}_{3}{ }^{-}$was retained in the organic-rich seep discharge zones, significantly reducing potential $\mathrm{NO}_{3}{ }^{-}$contributions to surface water. The average denitrification rates in the discharge seeps were approximately $45 \mathrm{mg} \mathrm{N} \mathrm{m}^{-2} \mathrm{~h}^{-1}$, or 3 times higher than the average channel rates (Richardson, unpublished data, 2007), confirming a high potential for microbial activity in the riparian surface environment.

\section{$\mathrm{NO}_{3}-$ Retention in Surface Water}

Unamended denitrification rates from each site were extrapolated to estimate reach-scale $\mathrm{N}$ loss due to denitrification. The highest rate of reach-scale $\mathrm{N}$ loss was in Morgan
Creek (0.019 $\left.\mathrm{mg} \mathrm{N} \mathrm{s}^{-1} \mathrm{~m}^{-1}\right)$, followed by Maple Creek (0.006 $\mathrm{mg} \mathrm{N} \mathrm{s}^{-1} \mathrm{~m}^{-1}$ ) and DR2 (0.002 $\mathrm{mg} \mathrm{N} \mathrm{s}^{-1} \mathrm{~m}^{-1}$ ) (Table 7). Reach-scale $\mathrm{N}$ loss from denitrification at Maple Creek surpassed DR2 despite lower areal rates due to greater bed area. At DR2 and Maple Creek, reach-scale denitrification rates were $<5 \%$ of the $\mathrm{NO}_{3}{ }^{-}$loss calculated from the difference between upstream plus ground water inputs minus downstream export. In contrast, the reach-scale denitrification rate at Morgan Creek could account for approximately 200\% of the whole-stream $\mathrm{NO}_{3}{ }^{-}$loss. Based on our denitrification enzyme assays, relatively shallow hyporheic exchange calculated for Morgan Creek (approximately $2.5 \mathrm{~cm}$ ) would adequately account for the $\mathrm{NO}_{3}{ }^{-}$retention in surface water.

When compared with the mass of $\mathrm{NO}_{3}{ }^{-}$transported in surface water, unamended denitrification rates extrapolated to the reach scale were only 0.2 to $3.5 \%$ of the surface water $\mathrm{NO}_{3}{ }^{-}$loads at all sites. These rates were unable to significantly reduce downstream $\mathrm{NO}_{3}{ }^{-}$transport at the high $\mathrm{NO}_{3}{ }^{-}$concentrations in the reaches. The low potential impact of denitrification on surface water at DR2 and Maple Creek was not surprising. Royer et al. (2004) found that even with relatively high potential denitrification rates, $\mathrm{NO}_{3}{ }^{-}$uptake velocities and lengths in five Illinois streams were so low that denitrification was not an efficient $\mathrm{N}$ sink for surface water $\mathrm{NO}_{3}{ }^{-}$. Relatively low $\mathrm{NO}_{3}{ }^{-}$uptake velocities (2.3-10.4 $\mathrm{mm} \mathrm{min}^{-1}$; Duff, unpublished data, 2007) calculated from the denitrification rates, and denitrification uptake lengths ranging from 56 to $179 \mathrm{~km}$ (Duff, unpublished data, 2007) confirmed that streambed denitrification in our streams was not an efficient $\mathrm{NO}_{3}{ }^{-} \sin \mathrm{k}$.

\section{Summary and Conclusions}

Ground water contributed 5 to $11 \%$ of the increase in stream flow along the reaches and 8 to $42 \%$ of gross $\mathrm{NO}_{3}{ }^{-}$inputs. Streambed processes potentially retained 45 to $75 \%$ of ground water $\mathrm{NO}_{3}{ }^{-}$before discharge to the stream. After accounting for these potentially high $\mathrm{NO}_{3}{ }^{-}$retention percentages, net $\mathrm{NO}_{3}{ }^{-}$inputs from ground water were a more modest 4 to $16 \%$ of the upstream plus ground water $\mathrm{NO}_{3}{ }^{-}$inputs, indicating that upstream surface inputs contributed the majority of $\mathrm{NO}_{3}{ }^{-}$to the reaches.

Within-stream $\mathrm{NO}_{3}{ }^{-}$loads increased along the study reaches due mainly to net ground water input and possibly streambed nitrification. In all streams, the cross-sectional area of the storage zone was a small percentage of the crosssectional area of the channel, and the median transientstorage time was low, indicating that transient storage was insignificant overall for surface water $\mathrm{NO}_{3}{ }^{-}$retention. Unamended denitrification rates extrapolated to the reach scale were unable to affect downstream $\mathrm{NO}_{3}{ }^{-}$transport at the high $\mathrm{NO}_{3}{ }^{-}$concentrations. Relatively low $\mathrm{NO}_{3}{ }^{-}$uptake velocities calculated from the denitrification rates and long denitrification uptake lengths confirmed that streambed denitrification was not an efficient $\mathrm{NO}_{3}{ }^{-}$sink of surface water $\mathrm{NO}_{3}{ }^{-}$.

Because of high $\mathrm{NO}_{3}{ }^{-}$loads in ground water, $\mathrm{NO}_{3}{ }^{-}$retention as a percentage of gross $\mathrm{NO}_{3}{ }^{-}$inputs was only notewor- 
thy in Maple Creek (>30\%), the organic-poor, autotrophic stream, which had the lowest denitrification potentials but highest chlorophyll $a, \mathrm{P} / \mathrm{R}$ ratio, $\mathrm{pH}, \mathrm{DO}$, and $\mathrm{DO}$ saturation. This was also the location where streambed processes potentially resulted in removal of $75 \%$ of ground water $\mathrm{NO}_{3}{ }^{-}$ . This suggests that $\mathrm{NO}_{3}{ }^{-}$was assimilated as ground water passed directly through benthic diatom beds.

Nitrate in ground water was effectively removed by assimilation or dissimilatory mechanisms in these agricultural settings, but once within the stream channel $\mathrm{NO}_{3}{ }^{-}$was effectively transported long distances due to high concentrations and limited bed contact.

\section{Acknowledgments}

This work was funded by two U.S. Geological Survey Programs, the National Water-Quality Assessment Program (NAWQA) and the National Research Program (NRP). We thank Erik Staub (USGS, Raleigh, NC), Hank Johnson (USGS, Portland, OR), Holly Weyer (USGS, Dover, DE), and Jill Frankforter (USGS, Lincoln, NE) for consultation and assistance with site logistics, field work, and light and photosynthesis measurements. We thank Lynn Bartsch and Jennifer Cavanaugh (USGS, La Crosse, WI) for field and laboratory assistance with the microbial assays. We also thank Frank Triska (USGS, Menlo Park, CA), Larry Puckett (USGS, Reston, VA), and two anonymous reviewers for reviewing this manuscript. The use of brand names in this paper is for identification purposes only and does not constitute endorsement by the U.S. Geological Survey.

\section{References}

Alexander, R.B., R.A. Smith, and G.E. Schwarz. 2000. Effect of stream channel size on the delivery of nitrogen to the Gulf of Mexico. Nature 403:758-761.

Bencala, K.E., and R.A. Walters. 1983. Simulation of solute transport in a mountain pool-and-riffle stream: A transient storage model. Water Resour. Res. 26:718-724.

Bencala, K.E. 1984. Interaction of solutes and streambed sediment: II. A dynamic analysis of coupled hydrologic and chemical processes that determine solute transport. Water Resour. Res. 20:1804-1814.

Bencala, K.E., D.M. McKnight, and G.W. Zellweger. 1990. Characterization of transport in an acidic and metal-rich mountain stream based on a lithium tracer injection and simulations of transient storage. Water Resour. Res. 26:989-1000.

Bernot, M.J., J.L. Tank, T.V. Royer, and M.B. David. 2006. Nutrient uptake in streams draining agricultural catchments of the Midwestern United States. Freshwater Biol. 51:499-509.

Bilby, R.E. 1981. Role of organic debris dams in regulating the export of dissolved and particulate matter from a forested watershed. Ecology 62:1234-1243.

Böhlke, J.K., J.W. Harvey, and M.A. Voytek. 2004. Reach-scale isotope tracer experiment to quantify denitrification and related processes in a nitrate-rich stream, mid-continent United States. Limnol. Oceanogr. 49:821-838.

Bower, C.E., and T. Holm-Hansen. 1980. A salicylate-hypochlorite method for determining ammonia in seawater. Can. J. Fish. Aquat. Sci. 37:794-798.

Broshears, R.E., K.E. Bencala, B.A. Kimball, and D.M. McKnight. 1993. Tracer-dilution experiments and solute-transport simulations for a mountain stream, Saint Kevin Gulch, CO. USGS Water-Resources Investigations Rep. 92-4081. USGS, Denver, CO.

Bukaveckas, P.A. 2007. Effects of channel restoration on water velocity, transient storage, and nutrient uptake in a channelized stream. Environ. Sci. Technol. 41:1570-1576.

Capel, P.D., K. McCarthy, and J. Barbash. 2008. National, holistic watershed-scale approach for studying agricultural chemicals. J. Environ. Qual. 37:983-993.

Cloern, J.E. 2001. Our evolving conceptual model of the coastal eutrophication problem. Mar. Ecol. Prog. Ser. 210:223-253.

D'Angelo, D.J., J.R. Webster, S.V. Gregory, and J.L. Meyer. 1993. Transient storage in Appalachian and Cascade mountain streams as related to hydraulic characteristics. J. N. Am. Benthol. Soc. 12:223-235.

Essaid, H.I., C.M. Zamora, K.A. McCarthy, J.R. Vogel, and J.T. Wilson. 2008. Temporal and spatial variability of streambed water flux in four agricultural watersheds. J. Environ. Qual. 37:1010-1023.

Fugita, D.K. 1969. Standard procedures for water analyses. Univ. of California, Davis, CA.

Galloway, J.N., W.H. Schlesinger, H. Levy, II, A. Michaels, and J.L. Schnoor. 1995. Nitrogen fixation: Atmospheric enhancement-environmental response. Global Biogeochem. Cycles 9:235-252.

Gooseff, M.N., R.O. Hall, and J.L. Tank. 2007. Relating transient storage to channel complexity in streams of varying land use in Jackson Hole, WY. Water Resour. Res. 43,W01417, doi:10.1029/2005WR004626.

Green, C.T., L.J. Puckett, J.K. Böhlke, B.A. Bekins, S.P. Phillips, L.K. Kauffman, J.M. Denver, and H.M. Johnson. 2008. Limited occurrence of denitrification in four shallow aquifers in agricultural areas of the United States. J. Environ. Qual. 37:994-1009.

Hale, R.L., and P.M. Groffman. 2006. Chloride effects on nitrogen dymanics in forested and suburban stream debris dams. J. Environ. Qual. 35:2425-2432.

Hall, R.O., and J.L. Tank. 2003. Ecosystem metabolism controls nitrogen uptake in streams in Grand Teton National Park, WY. Limnol. Oceanogr. 48:1120-1128.

Harvey, J.W., and B.J. Wagner. 2000. Quantifying hydrologic interactions between streams and their subsurface hyporheic zones. p. 4-44. In J.B. Jones and P.J. Mulholland (ed.) Streams and groundwaters. Academic Press, San Diego, CA.

Harvey, J.W., B.J. Wagner, and K.E. Bencala. 1996. Evaluating the reliability of the stream tracer approach to characterize stream-subsurface water exchange. Water Resour. Res. 32:2441-2451.

Hill, A.R., and D.J. Lymburner. 1998. Hyporheic zone chemistry and stream-subsurface exchange in two groundwater-fed streams. Can. J. Fish. Aquat. Sci. 55:495-506.

Hinkle, S.R., J.H. Duff, F.J. Triska, A. Laenen, E.B. Gates, K.E. Bencala, D.A. Wentz, and S.R. Silva. 2001. Linking hyporheic flow and nitrogen cycling near the Willamette River- a large river in OR, USA. J. Hydrol. 244:157-180.

Howarth, R., D. Anderson, J. Cloern, C. Elfring, C. Hopkinson, B. Lapointe, T. Malone, N. Marcus, K. McGlathery, A. Sharpley, and D. Walker. 2000. Nutrient pollution of coastal rivers, bays and seas. Issues Ecol. 7:1-15.

Inwood, S.E., J.L. Tank, and M.J. Bernot. 2005. Patterns of denitrification associated with land use in 9 midwestern headwater streams. J. N. Am. Benthol. Soc. 24:227-245.

Jackman, A.P., R.A. Walters, and V.C. Kennedy. 1984. Transport and concentration controls for chloride, strontium, potassium, and lead in Uvas Creek, a small cobble-bed stream in Santa Clara County, CA, USA: II. Mathematical modeling. J. Hydrol. 75:111-141.

Jones, J.B., S.G. Fisher, and N.B. Grimm. 1995. Nitrification in the hyporheic zone of a desert stream ecosystem. J. N. Am. Benthol. Soc. 14:249-258.

Kemp, M.J., and W.K. Dodds. 2001. Centimeter-scale patterns in dissolved oxygen and nitrification rates in a prairie stream. J. N. Am. Benthol. Soc. 20:347-357.

Kemp, M.J., and W.K. Dodds. 2002. Comparisons of nitrification and denitrification in prairie and agriculturally influenced streams. Ecol. Appl. 12:998-1009.

Laursen, A.E., and S.P. Seitzinger. 2002. Measurement of denitrification in rivers: An integrated, whole reach approach. Hydrobiologia 485:67-81.

Marzolf, E.R., P.J. Mulholland, and A.D. Steinman. 1994. Improvements to the diurnal upstream-downstream dissolved oxygen change technique for determining whole-stream metabolism in small streams. Can. J. Fish. Aquat. Sci. 51:1591-1599.

Matson, P.A., W.J. Parton, A.G. Power, and M.J. Swift. 1997. Agricultural intensification and ecosystem properties. Science 277:504-509.

Matson, P.A., W.H. McDowell, A.R. Townsend, and P.M. Vitousek. 1999. 
The globalization of $\mathrm{N}$ deposition: Ecosystem consequences in tropical environments. Biogeochemistry 46:67-83.

Morrice, J.A., H.M. Valett, C.N. Dahm, and N.E. Campana. 1997. Alluvial properties, groundwater-surface water exchange and hydrologic retention in headwater streams. Hydrol. Processes 11:253-267.

Moulton, S.R., J.G. Kennen, R.M. Goldstein, and J.A. Hambrook. 2002. Revised protocols for sampling algal, invertebrate, and fish communities as part of the National Water-Quality Assessment Program. USGS Open-File Rep. 02-150. USGS, Reston, VA.

Mulholland, P.J., H.M. Valett, J.R. Webster, S.A. Thomas, L.W. Cooper, S.K. Hamilton, and B.J. Peterson. 2004. Stream denitrification and total nitrate uptake rates measured using a field ${ }^{15} \mathrm{~N}$ tracer addition approach. Limnol. Oceanogr. 49:809-820.

Mulholland, P.J., E.R. Marzolf, J.R. Webster, D.R. Hart, and S.P. Hendricks. 1997. Evidence that hyporheic zones increase heterotrophic metabolism and phosphorus uptake in forest streams. Limnol. Oceanogr. 42:443-451.

Nolan, B.T. 1999. Nitrate behavior in ground waters of the southeastern USA. J. Environ. Qual. 28:1518-1527.

Nolan, B.T., and J.D. Stoner. 2000. Nutrients in ground water of the conterminous United States, 1992-1995. Environ. Sci. Technol. 34:1156-1165.

Peterson, B.J., W.M. Wolheim, P.J. Mulholland, J.R. Webster, J.L. Meyer, J.L. Tank, E. Marti, W.B. Bowden, H.M. Valett, A.E. Hershey, W.H. McDowell, W.K. Dodds, S.K. Hamilton, S. Gregory, and D.D. Morrall. 2001. Control of nitrogen export from watersheds by headwater streams. Nature 292:86-90.

Puckett, L.J., C. Zamora, H. Essaid, J.T. Wilson, H.M. Johnson, M.J. Brayton, and J.R. Vogel. 2008. Transport and fate of nitrate at the ground-water/surface-water interface. J. Environ. Qual. 37:1034-1050.

Richardson, W.B., E.A. Strauss, L.A. Bartsch, E.M. Monroe, J.C. Cavanaugh, L. Vingum, and D.M. Soballe. 2004. Denitrification in the Upper Mississippi River: Rates, controls, and contribution to nitrate flux. Can. J. Fish. Aquat. Sci. 61:1102-1112.

Royer, T.V., J.L. Tank, and M.B. David. 2004. Transport and fate of nitrate in headwater agricultural streams in Illinois. J. Environ. Qual. 33:1296-1304.

Runkel, R.L. 1998. One dimensional transport with inflow and storage (OTIS): A solute transport model for streams and rivers. USGS WaterResources Investigation Rep. 98-4018. USGS, Denver, CO. Available at http://co.water.usgs.gov/otis (verified 28 Nov. 2007).

Runkel, R.L. 2002. A new metric for determining the importance of transient storage. J. N. Am. Benthol. Soc. 21:529-543.

Seitzinger, S.P. 1988. Denitrification in freshwater and coastal marine ecosystems: Ecological and geochemical significance. Limnol. Oceanogr. 33:702-724.

Sheibley, R.W., J.H. Duff, A.P. Jackman, and F.J. Triska. 2003. Inorganic nitrogen transformations in the bed of the Shingobee River, MN Integrating hydrologic and biological processes using sediment perfusion cores. Limnol. Oceanogr. 48:1129-1140.

Sheibley, R.W., J.H. Duff, A.P. Jackman, F.J. Triska, E. Warren, and E.M. Godsy. 2006. Nitrate reduction in sediment perfusion cores from Pool 8, Upper Mississippi River, LaCrosse, WI, USA. Verh. Int. Verein.
Limnol. 29:1289-1295.

Smith, L.K., M.A. Voytek, J.K. Böhlke, and J.W. Harvey. 2006. Denitrification in nitrate-rich streams: Application of $\mathrm{N}_{2}$ :Ar and ${ }^{15} \mathrm{~N}$ tracer methods in intact cores. Ecol. Appl. 16:2191-2207.

Spalding, R.F., and M.E. Exner. 1993. Occurrence of nitrate in groundwater-a review. J. Environ. Qual. 22:392-402.

Strauss, E.A. 2000. The effects of organic carbon and nitrogen availability on nitrification rates in stream sediments. Ph.D. Thesis. Univ. of Notre Dame, Notre Dame, IN.

Strauss, E.A., N.L. Mitchell, and G.A. Lamberti. 2002. Factors regulating nitrification in aquatic sediments: Effects of organic carbon, nitrogen availability, and pH. Can. J. Fish. Aquat. Sci. 59:554-563.

Strauss, E.A., W.B. Richardson, L.A. Bartsch, J.C. Cavanaugh, D.A. Bruesewitz, H. Imker, J.A. Heinz, and D.M. Soballe. 2004. Nitrification in the Upper Mississippi River: Patterns, controls, and contribution to the $\mathrm{NO}_{3}^{-}$- budget. J. N. Am. Benthol. Soc. 2004:1-14.

Tesoriero, A.J., D.A. Saad, K.R. Burow, E.A. Frick, L.J. Puckett, and J.E. Barbash. 2007. Linking ground-water age and chemistry data along flow paths: Implications for trends and transformations of nitrate and pesticides. J. Contam. Hydrol. 94:139-155.

Tilman, D., J. Fargione, B. Wolff, C. D’Antonio, A. Dobson, R. Howarth, D. Schindler, W.H. Schlenger, D. Simberloff, and D. Swackhamer. 2001. Forcasting agriculturally driven global environmental change. Science 292:281-284.

Triska, F.J., J.H. Duff, and R.J. Avanzino. 1990. Influence of exchange flow between the channel and hyporheic zone on nitrate production in a small mountain stream. Can. J. Fish. Aquat. Sci. 47:2099-2111.

Triska, F.J., J.H. Duff, and R.J. Avanzino. 1993. The role of water exchange between a stream channel and its hyporheic zone in nitrogen cycling at the terrestrial-aquatic interface. Hydrobiologia 251:167-184.

Triska, F.J., V.C. Kennedy, R.J. Avanzino, G.W. Zellweger, and K.E. Bencala. 1989. Retention and transport of nutrients in a third-order stream in northwestern CA: Hyporheic processes. Ecology 70:1893-1905.

USEPA. 2006. Wadable streams assessment: A collaborative survey of the nation's streams. USEPA, Office of Water, Washington, DC. EPA 841B-06-002.

Valett, H.M., S.G. Fisher, and N.B. Grimm. 1990. Physical and chemical characteristics of the hyporheic zone of a Sonoran desert stream. J. N. Am. Benthol. Soc. 9:201-215.

Valett, H.M., J.A. Morrice, and C.N. Dahm. 1996. Parent lithology, groundwater-surface water exchange and $\mathrm{NO}_{3}$ - retention in headwater streams. Limnol. Oceanogr. 41:333-345.

Vitousek, P.M., J.D. Aberf, R.W. Howarth, G.E. Likens, P.A. Matson, D.W. Schindler, W.H. Schlesinger, and D.G. Tilman. 1997. Human alteration of the global nitrogen cycle: Sources and consequences. Ecol. Appl. 7:737-750

Young, R.G., and A.D. Huryn. 1998. Comment: Improvements to the diurnal upstream-downstream dissolved oxygen change technique for determining whole-stream metabolism in small streams. Can. J. Fish. Aquat. Sci. 55:1784-1785.

Zar, J.H. 1974. Biostatistical analysis. Prentice-Hall, Englewood, NJ. 